\title{
ROLUL VINOVĂȚIEI ÎN FUNCȚIONAREA \\ REMEDIILOR PENTRU NEEXECUTAREA
}

\author{
CONTRACTULUI
}

DOI: 10.24193 /SUBBiur.65(2020).4.25

Data publicării online:

16.03.2021

\section{Ionuț-Florin POPA*}

\begin{abstract}
O versiune similara a studiului a aparut in „Revista română de drept privat" nr. 4/2020, p. 339.
\end{abstract}

Rezumat: Principiul vinovăției este considerat, în mod tradițional, ca fiind fundamentul răspunderii civile. In materie contractuală, pentru o lungă perioadă de timp, s-a considerat că drepturile creditorului în ipoteza neexecutării sunt condiționate de existența vinovăției debitorului în neexecutare. Intrarea în vigoare a noului Cod civil a oferit prilejul unei ample dezbateri legate de condițile aplicării remediilor pentru neexecutarea contractului. Nucleul acestei dezbateri este chiar condiția vinovăției în activarea şi funcționarea remediilor. Studiul îşi propune să demonstreze că, în realitate, opoziția existentă între teza subiectivistă (potrivit căreia vinovăția este o condiție a remediilor) şi teza obiectivistă (care afirmă opusul) este una fără miză practică reală. In esență, vinovăția rămâne o simplă condiție a unei forme a neexecutării contractuale - încălcarea contractului şi nu o condiție a activării remediilor. Pe de altă parte, remediile sunt supuse unei varietăţi de reguli care fac adesea dificilă adecvarea lor la situația juridică pusă în discuție. Cu toate că factualismul stă la baza aplicării remediilor, o sumă de reguli aplicabile întregului sistem al remediilor este identificabilă pornind de la premisa că pentru orice neexecutare se găseşte remediul potrivit.

* Prof. univ. dr., Facultatea de Drept, Universitatea Babeș-Bolyai din Cluj, ionut.popa@ionutpopa.ro. 
Cuvinte-cheie: bona fides, bună-credință, culpam praestare, dauneinterese, excepția de neexecutare, executarea în natură, forța majoră, intenție, imposibilitatea fortuită de executare, încălcare a contractului, mora creditoris, neexecutare culpabilă, neexecutare fără justificare, neexecutare fortuită, neexecutare licită, neglijență, neglijență gravă, perpetuatio obligationis, prezumție de vinovăție, răspundere contractuală, rea-credință, vinovăție, remedii, rezoluțiune, sancțiune, vinovăție calificată.

\author{
THE ROLE OF CULPABILITY IN THE \\ OPERATION OF REMEDIES FOR THE NON \\ PERFORMANCE OF THE CONTRACT
}

\begin{abstract}
The principle of guilt is traditionally considered as being the basis of civil liability. In contractual matter, for a long period of time, it was considered that the rights of the creditor under the assumption of non performance were conditional upon the existence of the guilt of the debtor in non execution. The entry into force of the New Civil Code offered the opportunity of a broad based discussion related to the conditions for applying remedies for the non performance of the contract. The essence of these debates is represented by the condition itself of the guilt in the activation and operation of remedies. The study aims at demonstrating that, actually, the opposition existing between the subjectivist thesis (according to which guilt is a condition of remedies) and the objectivist thesis (which states the opposite) is without a real practical stake. In essence, guilt remains a simple condition of a form of contractual non performance - breach of contract -, and not a condition of activation of remedies. On the other hand, remedies are subject to a variety of rules which often make it difficult their suitability for the legal situation called into question. Although factualism underlies the application of remedies, a set of rules applicable to the entire system of remedies is identifiable starting from the assumption that the suitable remedy is found for any non performance.

Keywords: bona fides; good faith; culpam praestare; damages; plea of non performance; performance in kind; force majeure; accidental impossibility of performance; intent; breach of contract; mora creditoris; culpable non performance; non performance without justification; accidental non performance; illegal non performance; negligence; serious negligence; perpetuatio obligationis; presumption of guilt; contractual liability; bad faith; remedies; rescission; penalty; guilt; qualified guilt.
\end{abstract}




\section{Cuprins}

I. Despre relevanța dezbaterii asupra vinovăției ...................................... 856

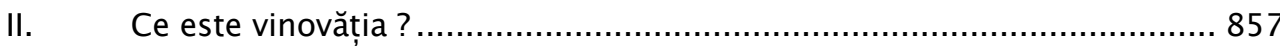

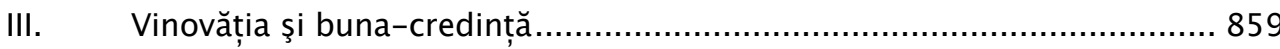

\section{A. A. Originea comună a bunei-credințe şi vinovăției în materie} contractuală 859

IV. B. Cât de relevantă este legătura dintre bună-credință şi vinovăție în sistemul actual al remediilor?

V. Problema vinovăției ca şi temei al activării remediilor

VI. Opinia tradițională, pretins sistemică, şi contradicțiile sale interne 869

VII. Opinia „utilitaristă” şi contradicțiile sale interne 876

VIII. Schema de interpretare logică a textelor legale................................... 880

IX. Căutarea răspunsului practic în jurisprudență?..................................... 894

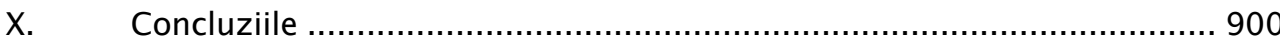

Intrucât tema volumului aniversar vizează, între altele, oscilația dreptului între evoluție şi revoluție, merită să ne întrebăm dacă noua reglementare a remediilor oferită de noul Cod civil (în principal, art. 1.516 urm. C.civ.) are, în raport cu vechea reglementare, dar şi în raport cu concluziile actuale ale dreptului comparat în materie, semnificaţia unei involuții, a unei evoluții, sau chiar a unei revoluții ? Că nu avem de a face cu o revoluție apare ca evident, originalitatea noii reglementări nefiind punctul ei forte. Rămâne să verificăm dacă este vorba de o evoluție sau de o involuție. In cele ce urmează, raportându-ne la un singur aspect al întregii teorii a remediilor, şi anume la tema vinovăției, vom observa că, deşi nivelul superior

\section{5}


de organizare al textelor legale atestă o evoluție, această „transformare ascendentă" a dreptului privat al contractelor simplifică aplicarea dreptului, dar conservă mult din substanța vechii reglementări. Cu alte cuvinte, întreaga reglementare a remediilor, se supune unei tendințe evolutive europene, doar că esența unuia din elementele-condiție a invocării remediilor rămâne relativ neschimbată, în pofida unor formulări diferite a textelor legale, în timp şi spațiu.

\section{Despre relevanța dezbaterii asupra vinovăției}

1. Unul din punctele nevralgice ale sistemului remediilor pentru neexecutarea contractului este chestiunea vinovăţiei. Doctrina (şi ceva mai puțin jurisprudența) se întreabă, în principal: în ce măsură este vinovăția debitorului o condiție pentru activarea dreptului la remedii ? In plan secund (cel mai controversat): este vinovăția o condiție pentru invocarea rezoluțiunii sau daunelor-interese ?

2. Scopul nostru este să răspundem acestor două întrebări oferind o schemă de răspuns unitară din punct de vedere logico-juridic. Răspunsul se bazează pe o interpretare a dreptului pozitiv incident, dar şi pe o analiză "revizionistă" a doctrinei şi jurisprudenței în materie. Odată oferit sau ales răspunsul, am găsit de cuviință să adăugam încă o întrebare: cât de importantă este cu adevărat, din perspectivă practică, să ne ataşăm unui punct de vedere?

3. Anticipând răspunsul, afirmăm că acesta este negativ şi că insistența dezbaterii a lăsat şi va lăsa jurisprudența neschimbată în materia remediilor. Teza noastră este aceea că, în realitate, vinovăția este doar un element-condiție a definiției neexecutării contractuale şi nicidecum o condiție

\section{6}


a accesului la remedii. Prin excepție însă, anumite remedii sunt proprii doar în contextul identificării elementului vinovăție. Dar şi în aceste cazuri, importanța elementului este uneori exagerată.

\section{Ce este vinovăția ?}

4. Răspunsul pe care îl dăm în această fază a prezentării este sumar, de circumstanță, dar suficient pentru scopul nostru. El ne ajută doar să stabilim coordonatele discuției care se va derula. Generic, vinovăţia sau culpa constituie reprezentarea psihologică a debitorului cu privire la caracterul ilicit pe care $\hat{1}$ are neexecutarea $\mathrm{sa}^{1}$.

5. Pentru definiția vinovăţiei avem în vedere câteva texte legale. Deşi legiuitorul nu ne oferă o definiție directă în sensul celor de mai sus, el are grijă să sublinieze în art. 16 C.civ. că reprezentarea psihologică de care vorbim acoperă intenția [alin. (2)] şi culpa [alin. (3)], respectiv să stabilească relația condițională între cele două atunci când legiuitorul condiționează efectele

\footnotetext{
${ }^{1} \mathrm{Nu}$ interesează în context o definire structurală a vinovăției. Pentru reperele ei, comune în materie delictuală şi contractuală, v. însă: M. Eliescu, Răspunderea civilă delictuală, Ed. Academiei R.S.R., Bucureşti, 1972, pp. 176 urm.; C. Stătescu, C. Bîrsan, Drept civil. Teoria generală a obligațiilor, Hamangiu, Bucureşți, 2008, pp. 196 urm.; L. Pop, Tratat de drept civil. Obligațiile, V. III, Raporturile obligaționale extracontractuale, Universul Juridic, Bucureșți, 2020, pp. 294 urm.; L. Pop, în L. Pop, I.F. Popa, S.I. Vidu, Curs de drept civil. Obligațiile, Universul Juridic, Bucureşti, 2015, pp. 351 urm., nr. 279 urm.; P. Vasilescu, Obligațiile, Ed a 2a, Hamangiu, 2017, pp. 634 urm.; F.I. Mangu, Răspunderea civilă. Constantele răspunderii civile, Universul Juridic, Bucureşti, 2014, pp. 220 urm.; L.R. Boilă, Vinovăția, fundament al răspunderii civile, în ambele sale forme, în textele noului Cod civil, ca şi în ale celui prevedent, în Dreptul nr. 1/2012, pp. 151 urm.; C. Jugastru, Drept civil. Teoria generală a obligațiilor, Universul Juridic, Bucureşti, 2017, pp. 153 urm.; F. A. Baias, V. Cîlțea, De la neexecutarea culpabilă la neexecutarea fără justificare a obligațiilor în dreptul civil român, în M. Nicolae, R. Rizoiu, L. Toma-Dăuceanu, In honorem Valeriu Stoica. Drepturi, libertăți şi puteri la începutul mileniului al III-lea, Universul Juridic, Bucureşţi, 2018, pp. 677 urm.
}

\section{7}


juridice de existența culpei [alin. (4)]². Textele, deşi au o portanță generală, sunt aplicabile şi temei speciale pe care o chestionăm în studiul de față. In plus, art. 1.358 C.civ. (un text aferent răspunderii delictuale pentru fapta proprie, dar egal aplicabil răspunderii contractuale) stabileşte un criteriu obiectiv intermediar de determinare a vinovăției: se va ține seama de un standard rezonabil de comportament aparținând unui om normal, abstract, un bonus pater familias care dă dovadă de diligență „față de interesele societății şi ale semenilor săi”' de timp, loc, spațiu în care a fost comisă fapta ilicită4.

6. Identificarea vinovăţiei ca şi element-condiție în cadrul sistemului remediilor pentru neexecutare este, din punct de vedere istoric, intim legată de apariția şi evoluția conceptului de bună-credință. Astfel cum vom putea observa, evoluția acestui din urmă concept este cea care a permis circumscrierea elementului vinovăție. O privire sumară asupra intimității relației bună-credință - vinovăție este de natură a rafina înțelegerea ultimei noțiuni, dar şi de a ne permite identificarea detaşării dintre cele două. Vom purcede aşadar, la o prezentare esențializată a relației istorico-juridice dintre buna-credință şi vinovăție pornind de la modelul evolutiv, întotdeauna util, oferit de dreptul roman.

\footnotetext{
${ }^{2}$ V. L. Pop, op.cit. - Raporturile obligaționale extracontractuale, pp. 298 urm., nr. 104.

${ }^{3}$ V. L. Pop, în L. Pop, I.F. Popa, S. I. Vidu, op.cit., p. 352, nr. 280.

${ }^{4} V$. M. Eliescu, op.cit., pp. 190 urm.
} 


\section{Vinovăția şi buna-credință}

\section{A. A. Originea comună a bunei-credințe şi vinovăției în materie contractuală}

7. Buna-credință în materie contractuală. Ce este buna-credință în materie contractuală ?5 In primul rând, buna-credință constituie un standard psihologic, care, în principiu, echivalează cu ignoranța ${ }^{6}$. Această accepțiune este însă tipică drepturilor reale, chiar dacă îşi găseşte o oarecare aplicabilitate şi în dreptul contractelor. In al doilea rând, ea este un standard proteiform de comportament în materie contractuală7 (vorbim, în acest caz,

\footnotetext{
${ }^{5}$ Am încercat să răspundem acestei întrebări într-un studiu recent pe care îl indicăm pentru utilizarea surselor bibliografice [v. I.-F. Popa, Buna-credință în dreptul contractelor. Genealogia, sursele și funcțiile bunei-credințe în dreptul contractelor, în M. Nicolae (ed.), Actul juridic civil. In honorem Gheorghe Beleiu, Solomon, Bucureşti 2020, pp. 41 urm.]. In cele ce urmează, în primele 4 paragrafe, ne vom folosi de referințele utilizate şi de observațiile făcute în acest studiu.

${ }^{6}$ V. G. Cornu, Bonne foi, în G. Cornu, Vocabulaire Juridique, 10e éd., Ed. Quadrige-PUF, Paris, 1987, p. 133: „Croyance erronée en l'existence d'une situation juridique régulière” care poate să cuprindă „Croyance reposant sur la seule ignorance (...)” și/sau „Croyance reposant sur une apparence trompeuse (...)”; adde Ph. le Tourneau, M. Poumarède, Bonne foi, în Répertoire de droit civil. Encyclopédie juridique Dalloz, janvier 2017, nr. 2-3; sau articolul Bonne foi, în S. Guinchard et alii, Lexique des termes juridiques 2018-2019, Ed. Dalloz, Paris, 2018, p. 141.

${ }^{7}$ V. J.P. Schmidt, în N. Jansen, R. Zimmermann, Commentaries on European Contract Laws, Oxford University Press, Oxford, 2018, p. 108, nr. 15; R. Zimmermann, în R. Zimmermann, S. Whittaker (eds.), Good Faith in European Contract Law, Cambridge University Press, Cambridge, 2000, pp. 63-92, p. 82; uneori, se adaugă și un al treilea sens bunei-credințe: cel de oficiu (officium) de interpretare/datorie de a acţiona (istoric identificabil în e.g., Cicero, De officiis, nr. VIII.35 și urm., pp. 327 și urm.), atât pentru normele contractuale, cât și pentru cele legale - v. D. Alland, S. Rials, Bonne foi, în D. Alland, S. Rials (ed.), Dictionnaire de la culture juridique, 1re éd., Ed. Quadrige-Lamy-PUF, Paris, 2003, p. 143; M. Floare, Buna şi reauacredință în negocierea şi executarea contractelor de drept comun în noul Cod civil şi în dreptul comparat, Universul Juridic, Bucureșți, 2015, pp. 83 urm.
}

\section{9}


de buna-credință subiectivă ${ }^{8}$ ). In fine, ambele accepțiuni ale bunei-credințe sunt dependente de o a treia expresie a sa - buna-credință ca şi criteriu de interpretare atât a normei contractuale, cât și a normei legale ${ }^{9}$ aplicabile contractului.

8. Principiul general al bunei-credințe. In materia obligațiilor, art. 1.170 C.civ. (inspirat din art. 1.201 PDEC, art. 1.7 şi 1.8 PICC 2004, respectiv art. 1375 C.civ. Québec) este cel care transpune principiul general al bunei-credințe din art. 14 în materia contractelor. Astfel, buna-credință este legal calificată ca un principiu director al încheierii şi executării contractelor. Nuanțarea principiului pentru faza încheierii contractului este prezentă în art. 1183 C.civ. (inspirat de 2.301 PDEC, 2.1.15 PICC 2004 şi probabil de art. 6.4 DCFR sau art. III.-1:103 DCFR, deşi acesta din urmă cuprinde o versiune mult mai amplă față de cea din codul nostru). Desigur că, sursele spun sau pot să spună multe despre semnificația bunei-credințe în materie contractuală.

9. Tradiția istorico-juridică a bunei-credințe. Apariția conceptului de bună-credință este datorată, în mare măsură, dreptului roman. Valorizarea sa de către juriştii romani a fost favorizată de decăderea ius civile şi de ascensiunea ius honorarium, o schimbare marcată de rolul prevalent al pretorilor în crearea dreptului $i^{10}$. In opoziția dintre aceste două surse ale dreptului, una conservatoare şi lipsită de elasticitate, calaltă reactivă

\footnotetext{
${ }^{8}$ V. F. Ranieri, Good Faith, în J. Basedow, K.J. Hopt, R. Zimmermann, A. Stier (ed.), The Max Planck Encyclopedia of European Private Law, vol. I, Ed. Oxford University Press, Oxford, 2012, p. 790.

${ }^{9}$ De altfel, această a treia accepțiune este inerentă concepției legiuitorului român, care a reunit cele două texte de principiu dedicate bunei-credințe (art. 14 și 15) în capitolul III al titlului preliminar, intitulat „Interpretarea și efectele legii civile”. $V$. M. Floare, op.cit., pp. 87 urm.

${ }^{10}$ V. P. Stein, Roman Law in European History, Cambridge, 1999, pp. 8 urm; pp. 18 urm.; H. Honsell, T. Mayer-Maly, W. Selb (Ed.), Römisches Recht, Springer, Berlin, 1987, pp. 220 urm.
} 
şi evolutivă, bona fides s-a cristalizat ca o reacţie necesară la imobilismul dreptului civil şi la strictețea procedurilor sale (legis actiones) ${ }^{11}$.

10. Acțiunile întemeiate pe buna-credință. La conceptualizarea bunei-credințe a contribuit semnificativ noțiunea de bonae fidei iudicia ${ }^{12}$. Acţiunile ex fide bona ${ }^{13} \mathrm{~s}$-au dezvoltat ca parte a procedurilor formulare (formulae) ce constituiau instrumentul judiciar pretorian prin care se concura instrumentul judiciar civil al acțiunilor legale (legis actiones) întemeiate pe legea strictă (adică Legea celor XII Table şi plebiscitele ulterioare adoptate) ${ }^{14}$. La un moment dat, greu de determinat cu precizie (a doua jumătate a secolului II î.d.Chr., iar după alți autori, abia în a doua jumătate a secolului I î.d.Chr. ${ }^{15}$ ), în cadrul acestor acțiuni s-a concretizat o categorie specifică ce a început să fie prezentă şi în edictul anual al pretorului: acțiunile bazate pe aşa-zisa oportere ex fide bona (acțiunile cerute de buna-credință sau fundamentate pe buna-credință), în contrast cu acțiunile simple bazate pe ius civile adică pe oporter $^{16}$. In contextul aceleiaşi bona fidei iudicia, a fost treptat recunoscută

\footnotetext{
${ }^{11}$ V. M. J. Schermaier, Bona fides in Roman contract law, în R. Zimmermann, S. Whittaker (eds.), Good Faith in European Contract Law, Cambridge, 2000, p. 65. Această „flexibilizare” a dreptului roman, a fost văzută de unii autori ca o slăbiciune care semnala decăderea dreptului roman [ $v$. J. W. Hedemann, Die Flucht in die Generelklauseln. Eine Gefahr für Recht und Staat, J.C.B. Mohr (Paul Siebeck), Tübingen, 1933, p. 2 (,Aber spätestens bei Justinian auch in materiellem Sinne, bis ins Ethische hinüberfließend: Statt Strenge Milde, statt Härte Weichlichkeit.").

${ }^{12}$ V. R. Zimmermann, The Law of Obligations. Romans Foundations of the Civilian Tradition, Oxford, 1996, pp. 277 urm.

${ }^{13}$ V. F. Ranieri, Europäisches Obligationenrecht. Ein Handbuch mit Texten und Materialien, 3. Aufl., Springer, Viena, 2009, pp. 1803 urm.

${ }^{14}$ Pentru tematică, $v$. M.D. Bob, Manual elementar de drept privat roman, Universul Juridic, Bucureșţi, 2019, pp. 69 urm.

15 V. M.J. Schermaier, art. precit., p. 71 (despre opiniile privind localizarea în timp şi aparţinând, prima lui Franz Wieacker, a doua lui Luigi Lombardi).

${ }^{16}$ V. M. J. Schermaier, în R. Zimmermann, S. Whittaker, op.cit., p. 74.
}

\section{1}


posibilitatea judecătorului roman de a admite sau de a respinge pe temeiuri de rea-credință acțiunea întemeiată pe orice contract (în sec. III d. Chr. optica era deja consacrată) ${ }^{17}$. Aşa-numita exceptio doli generalis seu praesentis presupunea posibilitatea respingerii unei acțiuni în virtutea excepției „de fiecare dată când exercițiul unui drept de către titularul său apărea ca evident contrar echităţii, ținând seama de diversele acorduri și relații existente între părți.”18 Treptat, juriștii romani au ajuns să considere că această excepție generală de dol este inerentă, în mod natural, exercițiului oricărei acțiuni (i.e. excepția nu trebuia invocată formal pentru ca o eventuală acțiune contrară bunei-credințe să fie respinsă) și de aici, inerentă natural, exercițiului oricărui drept subiectiviv, astfel încât Digestele o consacră ca soluție de drept cu valoare de regulă generală: (...) dolo facit quiumque id, quod quaqua exceptione elidi potest petit ${ }^{20}$.

${ }^{17}$ V. T. Duve, în M. Schmoeckel, J. Rückert, R. Zimmermann (ed.), Historisch-kritischer Kommentar zum BGB, B. II, Schuldrecht. Allgemeiner Teil, §§ 241-304, Mohr-Siebeck, Tübingen, 2007, p. 281; R. Zimmermann, op.cit. - Law of Obligations, p. 537, p. 674; M. J. Schermaier, în R. Zimmermann, S. Whittaker, op.cit., p. 84-85; F. Ranieri, Dolo petit contra pactum petat - Bona fides und stillschweigende Willenserklärung in der Judikatur des 19.Jahrhunderts, în Das Europäische Privatrescht des 19. Und 20. Jahrhunderts, Duncker \& Humblot, Berlin, 2007, pp. 331 urm., dar mai ales pp. 333 urm.; acelaşi autor, Bonne foi et exercice du droit dans la tradition du Civil law, în F. Ranieri, op.cit., pp. 417 urm.; în fine, acelaşi autor, L'eccezione di dolo generale nella tradizione del diritto romano comune, în $\mathrm{F}$. Ranieri, op.cit., pp. 459 urm.

${ }^{18}$ V. F. Ranieri, art. precit. - Bonne foi et exercice du droit dans la tradition du Civil law, p. 419 (unde sunt date ca exemple respingerea acțiunii formulate cu încălcarea unui pact de non petendo sau, mai interesant, respingerea acțiunii în revendicare de către cel care a vândut chiar cu nerespectarea formelor prescrise de ius civile).

${ }^{19}$ V. F. Ranieri, art. precit. - Bonne foi et exercice du droit dans la tradition du Civil law, p. 419 (unde se arată că astfel a fost uitată antiteza tradițională între soluțiile de procedură și soluțiile substanțiale de drept).

${ }^{20}$ Digeste 44.4.2.5 [Extras din edictul pretorului Ulpian („Et generaliter sciendum est ex omnibus in factum exceptionibus doli oriri exceptionem, quia dolo facit, quicumque id, quod quaqua exceptione elidi potest, petit: nam et si inter initia nihil dolo malo facit, attamen nunc

\section{2}


11. Tradiția vinovăţiei. In această evoluție, fără a putea preciza cu exactitate momentele sale istorice, şi-a făcut apariția şi elementul vinovăție. In dreptul roman vechi, surprinzător, în materie delictuală, locul vinovăției era limitat spre inexistent, în sensul că răspunderea delictuală din dreptul roman, în forma sa civilă oferită de Lex Aquilia (cca 286 î.d.Chr.), era calificabilă după standardele actuale ca o răspundere de drept strict sau mai exact, ca o răspundere delictuală obiectivă ${ }^{21}$. Spre sfârşitul secolului III î.d.Chr. şi condițiile răspunderii delictuale s-au rafinat şi elementul culpă a devenit o condiție a acesteia ${ }^{22}$. Această etapă este de reținut pentru că definiția culpei oferită în context delictual s-a generalizat şi constituie chiar şi astăzi, baza definiției actuale a vinovăției, atât în materie contractuală cât şi delictuală. Evoluția existentă în materie delictuală a fost oarecum similară şi în materie contractuală, dar progresul a fost intim legat de procedurile formulare ale bunei-credințe.

petendo facit dolose, nisi si talis sit ignorantia in eo, ut dolo careat” - „Dol comite acela care pretinde ceva ce poate fi anulat sau respins de îndată ca urmare a oricărei apărări sau excepții”)].

${ }^{21}$ V., de pildă B. Winiger, Responsability, Restauration and Fault, Intersentia, CambridgeAntwerp-Portland, 2018, p. 57 urm. care, în comentariul său pe marginea răspunderii inaugurate de Lex Aquilia subliniază lipsa exigenței culpei. Interpretarea (aparținând şî altor autori) se bazează, în principal pe trei texte ale Digestelor lui Iustinian (D. 9.2.2 Gaius; D. 9.2.27.5 Ulpian; D. 9.2.5.1 Ulpian).

22 Devenită regulă în epoca republicană târzie [H. Honsell, T. Mayer-Maly, W. Selb (Ed.), op.cit., p. 365]. Datorată, se pare, jurisconsultului Mucius care a oferit (în circumstanțele unei spețe extrem de banale) rudimentele unei definiții a culpei care constituie şi astăzi un model pentru judecător: "când judecățorul evaluează vinovăţia, el evaluează comportamentul autorului faptei prejudiciabile în raport cu standardul de diligență al lui diligens binus vir" ( $v$. B. Winiger, op.cit., p. 62). Sursa istorică este D. 9.2.31 [„,(...) culpam autem esse, quod cum a diligente provideri poterit, non esset provisum aut tum denuntiatum esset, cum periculum evitari non possit (...)/există o culpă atunci când ceea ce putea fi prevăzut de un om diligent nu a fost prevăzut sau când avertizarea a fost făcută prea târziu pentru ca pericolul să mai poată fi evitat." - ed. Krueger/Mommsen, V. 1, p. 123; trad. după A. Watson, The Digest of Justinian, University of Pennsylvania Press, Philadelphia, 1998, V. 1, p. 288).

\section{3}


12. Doctrinele centrale ale vinovăţiei. Chiar dacă în dreptul roman timpuriu nu se putea vorbi de o răspundere contractuală cu valoare generală ${ }^{23}$, procedura formulară a dat startul unei răspunderi contractuale tot obiective $^{24}$ prin recunoaşterea acțiunii întemeiate pe obligatio dandi certam rem care a devenit o acțiune stricti iuris. Evoluția ulterioară a dreptului roman în această privință este marcată de apariția a trei teorii, toate extrem de importante pentru înțelegerea sistemului actual al remediilor prin prisma vinovăției: i. prima este teoria perpetuatio obligationis - această construcție juridică, prin intermediul unei ficțiuni (şi anume considerarea bunului ce trebuia predat creditorului potrivit contractului ca fiind încă în ființă), permitea obligarea debitorului vinovat de pieirea bunului la plata de dauneinterese ${ }^{25}$; ii. a doua, mult mai importantă pentru juristul modern, este teoria culpam praestare - ea permitea judecătorului să decidă dacă evenimentul care genera imposibilitatea de executare sau care genera o executare defectuoasă îi era sau nu imputabil debitorului, pentru ca, în prima situație

${ }^{23}$ V. J. Gordley, In defense of Roman contract law, în P. G. Monateri (ed.), Comparative Contract Law, Edward Elgar, Cheltenham -Northampon, 2017, pp. 35 urm. (pentru distincția romană între contracte bonae fidei şi contracte stricti iuris şi evoluţia factuală a răspunderii contractuale în funcție de această distincție).

${ }^{24}$ V. ptr. calificare, F. Ranieri, op.cit. - Europäisches Obligationenrecht, p. 555 („Strikte objektive Haftung des säumigen Schuldners").

${ }^{25}$ In formula inițială romană, obligația nu mai putea exista dacă bunul asupra căruia purta prestația nu mai exista el însuşi (pentru evoluția noțiunii de imposibilitate şi pentru explicaţiile contradictorii oferite de comentatori textelor romane eferente, $v$. magistralul studiu al lui $\mathrm{J}$. Gordley, Impossibility and Changed and Unforeseen Circumstances, în The American Journal of Comparative Law, V. 52, 2004, Summer, pp. 513 urm.). Ficțiunea perpetuării obligației permitea condamnarea debitorului la despăgubiri [conceptul a fost identificat în Pauli Sententiae V.VII. 4 („ac si ea res extartet”) şi în Digeste 45.1.82.1 Ulpian („perinde ac si homo viveret"), sens în care, $v$. R. Zimmermann, op.cit., p. 784 urm.; F. Ranieri, op.cit. Europäisches Obligationenrecht, p. 556].

\section{4}


acesta să poată fi condamnat pecuniar ${ }^{26}$; iii. în fine, teoria mora debitoris, potrivit căreia debitorul era ținut răspunzător față de creditor chiar dacă imposibilitatea executării corespunzătoare a obligației era datorată unui eveniment fortuit dacă acest eveniment a intervenit după momentul la care obligația trebuia executată potrivit contractului ${ }^{27}$.

13. Generalizarea tradiţiei şi moştenirea europeană. Evoluția procedurilor formulare în materia bunei-credințe a oferit, în cele din urmă, în dreptul roman, o versiune conjugată a celor două noțiuni (bună-credință şi vinovăție): sub imperiul acțiunilor bona fide se considera că debitorul nu trebuie doar să execute obligația contractuală, ci trebuie să facă tot ceea ce este necesar pentru atingerea scopului contractual şi să se abțină de la orice va duce la privarea creditorului de scopul pentru care a încheiat contractul. In această privință, doctrina culpam praestare implica o judecată de valoare cu privire la o culpabilă lipsă de diligență a debitorului în executarea contractului ${ }^{28}$. Aşadar, standardul de evaluare a comportamentului constituia punctul de legătură între cele două noțiuni (i.e., vinovăție şi bună-credință $)^{29}$,

\footnotetext{
${ }^{26}$ Extrem de relevantă pentru identificarea noțiunii de culpa în materie contractuală, teoria a servit la evaluarea vinovăției din perspectiva dezaprobării comportamentului debitorului în raport cu comportamentul care putea fi aşteptat de la acesta conform preceptelor lui „ius" şi „mos" (v. R. Zimmermann, op.cit., p. 786). Exemplele sunt cazuale, aproape ca întotdeauna în dreptul roman: Digeste 45.1.91 Paulus (cel care a promis un sclav care a decedat ulterior încheierii contractului pentru că nu a primit tratament medical din partea debitorului, rămâne obligat față de creditor). Exemplul subliniază obligația de diligență pe care trebuie să o aibă debitorul în executarea obligațiilor sale şi este extrem de relevant pentru evaluarea neexecutării prin prisma bunei-credințe văzută ca standard de comportament onest.

27 Am spune: debitorul rămâne responsabil dacă pieirea bunului se produce fortuit după momentul la care trebuia efectuată predarea ( $v$. R. Zimmermann, op.cit., p. 787).

${ }^{28}$ V. F. Ranieri, op.cit. - Europäisches Obligationenrecht, p. 556.

${ }^{29}$ In general, standardul obiectiv bonus pater familias. Intre alte pasaje, D. 45.1.137.2 este considerat un reper [Venuleius, inter alia, „(...) quod autem accipi debeat, quaeritur et magis est, ut totam eam rem ad iudicem, id est ad virum bonum remittamus, qui aestimet, quanto
}

\section{5}


fără să însemne că ele se identificau, ci doar că se intersectau şi se deserveau reciproc. Situația se prezintă relativ identic şi în dreptul modern. Cu toate acestea, în privința componentei daunelor-interese, evoluția continentală a dreptului a dobândit, sub influența dreptului canonic, o componentă subiectivă semnificativă. Intr-o anumită măsură, s-a încercat fundamentarea răspunderii contractuale pe ideea de greşeală morală, astfel încât, într-o anumită măsură s-a renunțat la standardul obiectiv al vinovăției ${ }^{30}$. In influentul tratat al lui Pothier, ideea vinovăției în materia daunelor-interese este menținută alături de perechea sa antagonică de forță majoră - casus ${ }^{31}$, potrivit căreia, dacă debitorul nu probează un casus, atunci înseamnă că este vinovat de neexecutare. Atât standardul vinovăției ca şi condiție pentru daune-interese, cât şi raportul dintre vinovăţie şi forță majoră, respectiv dintre vinovăție şi bună-credință au trecut din ius commune în reglementările moderne continentale. Probabil că produsul lor intelectual-juridic cel mai consistent îl constituie astăzi prezumția de culpă în materie contractuală.

tempore diligens pater familias conficere possit, quot facturum se promiserit/” „(...) e de preferat să îi cerem judecătorului, ca unui om onest, care va aprecia momentul executării (obligației de plată - n.n.) ținând seama de cum ar trebui să o facă un om conştiincios cu promisiunile sale (...)”]. $V$. T. Rüfner, în N. Jansen, R. Zimmermann (ed.), op.cit., p. 1166, nr. 5 .

${ }^{30}$ Ptr. observație, $v$. T. Rüfner, în N. Jansen, R. Zimmermann (ed.), op.cit., p. 1168, nr. 9. Poate că ar fi mai corect să spunem însă, nu că standardul obiectiv pater familias a dispărut şi a fost înlocuit cu o viziune care lega neexecutarea de doctrina creştină a păcatului, cât mai degrabă că vechiul standard pater familias fost înlocuit de standardul nou al „bunului creștin”.

${ }^{31}$ V. R.-J. Pothier, Traité des obligations, Paris, 1764, reed. Dalloz, Paris, 2011, pp. 61, nr. 142, 67 urm., nr. 159 urm. 
IV. B. Cât de relevantă este legătura dintre bună-credință şi vinovăție în sistemul actual al remediilor?

\section{Intre bună-credință şi rea-credință există o zonă} neacoperită ? Dacă răspunsul este negativ, înseamnă că vinovăţia este egalul relei-credințe şi că toate neexecutările nejustificate ale obligațiilor contractuale sunt neexecutări cu rea-credință. Dacă răspunsul este pozitiv, înseamnă că vinovăția acoperă o plajă mai largă de atitudini psihologice şi cu relevanță juridică ale debitorului între care reaua-credință este doar o modalitate. Credem că răspunsul este pozitiv, în sensul că nu toate neexecutările fără justificare (după formula art. 1.516 C.civ.) sunt neexecutări cu rea-credință. Pentru a fi vorba de rea-credință este necesar să existe ceea ce se chema tradițional „dol” sau intenție. Dreptul modern (urmând o îndelungată tradiție în materie) asimilează acestei intenții şi culpa (sau neglijența) grave.

\section{Buna-credință nu înseamnă totdeauna lipsa vinovăției.} Intre bună/rea-credință şi lipsa de vinovăție există o înrudire, dar nu o identitate. Istoric, buna-credință şi vinovăția îşi au ambele originea în acelaşi fapt istorico-juridic: procedurile formulare. Dacă lipsa oricărei vinovăţii în neexecutarea contractului este egalul bunei-credințe a debitorului (e.g. dacă debitorul, dornic să execute este împiedicat de o forță majoră, el va fi considerat de bună- credință şi în acelaşi timp nevinovat), nu se poate spune că şi reversul este valabil şi anume că neexecutarea vinovată sau culpabilă este o neexecutare cu rea-credință - e.g., neplata prețului unei vânzări din pricina incapacității financiare a debitorului înseamnă neexecutare culpabilă [pentru că art. 1.634 alin. (6) C.civ. instituie o răspundere obiectivă pentru obligațiile care au ca obiect bunuri de gen], dar nu înseamnă totdeauna şi

\section{7}


neexecutare cu rea-credință. Poate fi însă vorba de rea-credință dacă, de pildă, debitorul, în mod intenționat, şi-a provocat insolvabilitatea ca să nu mai poată să-şi execute obligația contractuală [ipoteză vizată de art. 1.417 alin. (1) şi (2) C.civ.] sau dacă debitorul sub condiție a împiedicat cu rea-credință îndeplinirea acesteia sau dimpotrivă, dacă creditorul sub condiție determină cu rea-credință producerea evenimentului [art. 1.405 alin. (1) şi (2)].

16. Reaua-credință ca formă de vinovăţie. In dreptul curent, prin rea-credință în materia neexecutării contractuale (ca opus natural al bunei-credințe) înțelegem o formă calificată de vinovăție, adică, în linia de interpretare a art. 16 C.civ., neexecutarea cu intenție (atunci când debitorul a prevăzut rezultatul faptei sale şi fie a urmărit, fie a acceptat producerea acestui rezultat). Legiuitorul diferențiază, în privința remediilor, aceste două categorii. De pildă, nu este valabilă clauza prin care vânzătorul este exonerat de răspunderea pentru evicțiunea rezultată din fapta proprie sau din fapte anterioare vânzării pe care acesta le cunoştea, dar le-a ascuns cumpărătorului (art. 1.699 C.civ.). Această formă de vinovăție este asimilabilă intenției sau neglijenței grave (ultima, fiind tradițional considerată ca absorbită de intenție şi implicând un tratament juridic identic).

\section{Observație generală privind raportul dintre buna-} credință şi lipsa de vinovăție. Putem oare să extragem o învățătură din lipsa de identitate dintre buna-credință şi lipsa de vinovăție ? Identificarea zonei gri dintre cele două, ne ajută să înțelegem că neexecutarea vinovată atrage remediile curente, în timp ce neexecutarea cu rea-credință poate atrage remedii suplimentare pe lângă cele curente. Exemplul curent îl constituie ipoteza daunelor-interese pentru neexecutarea cu intenție (i.e. reacredință) sau gravă neglijență (idem) a obligațiilor contractuale. In acest caz, despăgubirile ies din matca firească a previzibilităţii şi pot să acopere şi 
prejudiciul care nu era previzibil în raport cu momentul încheierii contractului ( $v$. ipoteza tradițională reglementată de art. 1.533 C.civ.).

\section{Problema vinovăției ca şi temei al activării remediilor}

18. Cele de mai sus constituie o introducere necesară şi o fixare aproximativă a termenilor discuției. Pentru a readuce discuția în planul sistemului remediilor pentru neexecutare, vom încerca o prezentare a opiniei tradiționale în materie de remedii (V); apoi a opiniei „utilitariste” (VI); vom identifica apoi o schemă de interpretare logică a textelor legale relevante (VII); vom căuta răspunsul practic necesar (VIII); vom trage câteva concluzii legate de tema abordată (IX).

VI. Opinia tradițională, pretins sistemică, şi contradicțiile sale interne

19. In prezentarea remediilor, atât din punct de vedere istoric, cât şi ideatic, se poate spune că două mari teze se confruntă. Una dintre ele accentuaeză condiționarea activării drepturilor creditorului de elementul vinovăție (teza subiectivă). Cealaltă, apreciază că elementul vinovăție nu este o condiție a remediilor, ci o condiție a încălcării contractului (teza obiectivă, recalificată ca „utilitaristă”). In realitate, în niciuna din cele două teze nu este universalizată sau dimpotrivă, eliminată în întregime, condiția vinovăției. In acest relativism al celor două teze stă, de fapt, identitatea lor practică, astfel cum vom putea observa.

20. Legitățile teoriei subiective. Opinia subiectivistă se bazează pe o serie de reguli, explicit sau implicit asumate. Vom încerca să oferim, în 
sinteză, aceste reguli de fond, raportându-ne la textele actualului Cod civil: (i) teza vizează, în principal, o pretinsă interpretare generalizantă a art. 1.516 alin. (2) C.civ., în sensul că vede în text un numerus clausus al ipotezelor în care se pot aplica remedii - ipotezele în care neexecutarea este nejustificată ${ }^{32}$; (ii) pentru ca creditorul să poată accede la remediile oferite de textul legal (mai cu seamă, la excepția de neexecutare, executarea silită în natură, rezoluțiunea33 şi daunele-interese) este necesară îndeplinirea condiției

\footnotetext{
${ }^{32} \mathrm{Cu}$ excluderea evidentă a aplicării remediilor la alte ipoteze, cum ar fi neexecutarea justificată de imposibilitatea fortuită de executare [v., de pildă, V. Stoica, Ințelesul noțiunilor de rezoluțiune şi reziliere în Codul civil român. Intre dezideratul clarității şi fatalitatea ambiguității, în RRDP nr. 4/2013, pp. 9 urm.: „rezoluțiunea şi rezilierea sunt sancțiuni pentru neexecutarea nejustificată (culpabilă) a contractului, în timp ce imposibilitatea fortuită de executare ridică problema repartizării riscului contractului între părțile care l-au încheiat” - în note este criticată tendința extinderii domeniului rezoluțiunii la ipotezele de neexecutare fortuită; pe larg, $v$. nr. 4).

${ }^{33}$ V., de pildă, Cas. I, dec. nr. 537/1915, în Codul civil adnotat (C. Hamangiu), V. II, All Beck, Restitutio, Bucureşți, 1999, nr. 9, p. 571; T.S., col. civ., dec. civ. nr. 2299/1955, în LP nr. 1/1956; sau T.S., col. civ., dec. nr. 2266/1984, în C.D. 1984, p. 96. Pentru doctrina de azi, $v$. V. Stoica, Rezoluțiunea şi rezilierea contractelor civile, All, Bucureşti, 1997, pp. 54 urm., nr. 31-32; N. Daghie, Rezoluțiunea şi rezilierea contractelor, Universul Juridic, Bucureşti, 2013, pp. 123 urm.; G. Boroi, L. Stănciulescu, op.cit., p. 181 urm.); C.E. Zamşa, în F. Baias, E. Chelaru, R. Constantinovici, I. Macovei, C.H. Beck, Bucureşti, 2014, p. 1752, nr. 6 urm.; nuanțat, în sensul că vinovăția este prezumată, v. V. Stoica, art. precit.- Fundamentul rezoluţiunii şi al rezilierii, pp. 18-19; într-o altă lucrare, se deplânge diminuarea rolului unor condiții tradiționale ale rezoluțiunii, între care şi vinovăţia: „Diferitele legislații naționale fie nu mai recunosc principiul general al rezoluțiunii, încercând să reglementeze cazurile particulare în care este admisibilă rezoluțiunea, fie nu disting între neexecutarea culpabilă şi neexecutarea fortuită, fie interzic cumulul rezoluțiunii cu daunele-interese, fie oscilează între acceptarea rolului judecătorului şi declarația unilaterală de rezoluțiune.” (V. Stoica, art. precit. - Ințelesul noțiunilor de rezoluțiune şi reziliere în Codul civil român. Intre dezideratul clarității şi fatalitatea ambiguității, p. 14); L. Toma-Dăuceanu, La résolution unilatérale. Droit comparé francoroumain, IRJS, Paris, 2016, p. 168, nr. 200 (în sensul că imputabilitatea este o condiție generală impusă de art. 1.516 C. civ.).
}

\section{0}


substanțiale a vinovăției; (iii) teza manifestă o oarecare mefiență (valabil doar pentru unii autori) față de noțiunea de remedii ${ }^{34}$.

21. Tradiția juridică a tezei subiective. Această teză îşi are filonul în dreptul roman clasic şi presupune ideea generală că sancțiunile aflate la îndemâna creditorului (remediile pentru neexecutare) sunt accesibile numai dacă este îndeplinită şi condiția vinovăției debitorului în neexecutarea obligațiilor sale contractuale 35 . Soluția a făcut carieră în codurile moderne, în principal în privința daunelor-interese contractuale ${ }^{36}$. Ea era regula în cazul răspunderii contractuale din dreptul francez (fostul art. 1147 C.civ. fr. ${ }^{37}$ ); în

${ }^{34}$ Unii autori repudiază explicit termenul remedii considerând că există suficiente argumente pentru menținerea termenului „sancțiuni” [v. M. Nicolae, Natura juridică a „remediilor” (sancţiunilor) contractuale, în M. Nicolae, R. Rizoiu, L. Toma-Dăuceanu, In honorem Valeriu Stoica. Drepturi, libertăţi şi puteri la începutul mileniului al III-lea, op.cit., pp. 582 urm. (în special, pp. 596 urm.)]. Alți autori rămân ataşaţi termenului „sancțiune”, deşi constată că noua reglementare „a renunțat însă, de principiu, la criteriul imputabilității, la neexecutarea culpabilă a contractului, în aranjarea mijloacelor oferite creditorului neplătit.” (P. Vasilescu, Obligațiile, Hamangiu, Bucureșți, 2017, p. 527). Preferința pentru „sancțiuni” este moştenită din dreptul canonic unde ideile de sancţiune şi culpă sunt legate pentru că nu era considerată admisibilă aplicarea unei sancțiuni decât pentru o faptă comisă din culpă. Conținutul moral al ideii de sancțiune obliga la aceasta. Pentru rezoluțiune, v. F. Terré, E. Simler, Y. Lequette, F. Chénedé, Droit civil. Les obligations, Dalloz, Paris, 2017, p. 852, nr. 794; în general, $v$. J. Witte Jr., F.S. Alexander, Christianity and Law. An Introduction, Cambridge University Press, 2008, p. 127 urm.; Zimmermann, op.cit., p. 576 urm.

${ }^{35}$ V. supra, partea a III-a.

${ }^{36}$ Pentru că nu aceeaşi observație se poate face în privinţa tuturor celorlalte remedii pentru neexecutare. Ptr. daune-interese, $v$. R.-J. Pothier, op.cit., p. 68, nr. 161; R. von Jhering a afirmat în susținerea acestei tradiții că vinovăția este la fel de indispensabilă pentru daunele-interese precum oxigenul este pentru flacără [apud. T. Rüfner, în N. Jansen, R. Zimmermann (ed.), op.cit., p. 1168, nr. 9].

${ }^{37}$ Art. 1147 C.civ. fr. prevedea indirect că principiul în materia răspunderii este cel al vinovăției indicând că debitorul este ținut la daune-interese dacă nu este în măsură să justifice printr-o cauză străină neimputabilă lui neexecutarea sau executarea cu întârziere a obligațiilor sale [ „(...) toutes les fois qu'il ne justifie pas que l'inexécution provient d'une cause étrangère qui ne peut lui être imputée (...)"]. Deşi în mod tradițional textul este văzut ca fondator al răspunderii bazate pe vinovăție, el a fost adesea calificat ca instituind o prezumție de vinovăție în sarcina 
dreptul elvețian (art. 99 C. elvețian al obligațiilor ${ }^{8}$ ); în dreptul austriac (§ 920 şi § 1295 ABGB39); şi, în mod special, în dreptul german (§ 276 BGB40). In

debitorului („Le seul intérêt du texte - mais il est considèrable - est de présumer que l'inexécution est le fait du débiteur: il incombe au débiteur d'établir une cause étrangère." - v. H. et L. Mazeaud, J. Mazeaud, F. Chabas, T. II, V. 1, Obligations. Théorie générale, ge éd. par F. Chabas, Montchrestien, Paris, 1998, p. 443, nr. 435). Textul a fost înlocuit în anul 2016 de art. 1231-1 care menține aceeaşi regulă, arătând că debitorul poate fi obligat la daune-interese dacă neexecutarea nu este justificată de o cauză de forță majoră [,,(..) s'il ne justifie pas que l'inexécution a été empêchée par la force majeure."]. Istoricul reglementării îl are în centrul atenției pe Domat [„,Toutes les pertes et tous les dommages qui peuvent arriver par le fait de quelque personne (...) doivent être réparés par celui dont l'imprudence ou autre faute y a donné lieu. Car c'est un tort qu'il a fait, quand même il n'aurait pas eu l'intention de nuire" (Les Loix civiles dans leur ordre naturel, L. II, t. VIII, S. IV, $\mathrm{n}^{\circ} 1$, apud Ph. Le Tourneau, Rép. de dr. civ. Dalloz, Responsabilité: généralités (mai 2009, actualisation -janvier 2020), nr. 109; adde H. Boucard, Responsabilité contractuelle (juillet 2018, actualisation - juillet 2020), Rép. de dr. civ. Dalloz, nr. 372.

${ }^{38}$ Art. 99 alin. (1) C. elvețian al obligațiilor („En général le débiteur répond de toute faute”). Textul are o valoare generală şi se consideră că instituie o condiționare generală a remediilor de existența vinovăției, fără însă a exclude excepțiile. Principiul general al vinovăției statuat de alin. (1) se aplică şi în materie contractuală, potrivit alin. (3) al aceluiaşi articol (v. P. Tercier, P. Pichonnaz, Le droit des obligations, 6e éd., Schulthess, Genève-Zurich, 2019, p. 282; I. Schwenzer, Schweizerisches Obligationenrecht. Allgemeiner Teil, Sechste Aufl., Stämpfli, Bern, 2012, pp. 77 urm. - unde se poate observa o scădere spre dispariție a interesului pentru condiția vinovăției, fie şi dacă este vorba de daune-interese).

${ }^{39} \S 920$ ABGB conferă remediile daunelor-interese şi rezoluțiunii numai pentru neexecutarea cu vinovăție (Erfüllung durch Verschulden vereitelt). § 1295 ABGB condiționează acordarea daunelor-interese de vinovăție (Verschulden).

$40 § 276$ par. (1) BGB care consacră răspunderea debitorului (Verantwortlichkeit des Schuldners, trebuie înțeles ca referindu-se la toate remediile pentru neexecutare, nu doar la daunele-interese) pentru toate neexecutările dacă acestea sunt comise/omise cu intenție (Vorsatz) sau neglijență (Fahrlässigkeit). Mai mult, printr-o conectare directă la tradiția romană a culpam praestare, potrivit par. (2) debitorul este ținut răspunzător în cazul în care nu depune diligențele rezonabile în executarea obligațiilor sale. Forma actuală a acestui text, caracterizat ca reprezentativ în galeria codificărilor principiului vinovăției (Verschuldenprinzip), admite, începând cu reforma din anul 2002, şi o răspundere care nu este bazată pe culpă, dar care are natura unei excepții. Această excepție majoră se referă, în realitate, chiar la răspunderea contractuală - este vorba de actuala reglementare a § 280 BGB care guvernează toate ipotezele în care prejudiciul a fost cauzat ca urmare a încălcării unei îndatoriri rezultate dintr-o obligație concretă preexistentă. Excepția funcționează în sensul general potrivit căruia, în materie contractuală, operează prezumția de culpă $(v$. R. Schulze, în G.

\section{2}


dreptul românesc anterior reformei din anul 2011, regula era cea preluată din art. 1147 C.civ. fr. (art. 1082 V. C. civ. fiind o traducere a versiunii franceze ${ }^{41}$ ).

22. Contradicțiile interne. Potrivit acestei teze, în principiu, vinovăția este o condiție a remediilor pentru neexecutare, cu excepția prevederilor exprese contrare. Aşadar, teza lasă să fie considerate excepții numeroasele cazuri în care este de notorietate că nu se poate impune condiția vinovăției. Interesul special pentru această condiție este mai cu seamă exprimat în materia rezoluțiunii pentru neexecutare, unde se susține, în

Dannemann, R. Schulze, German Civil Code, V. I, Books 1-3, Article-by-Article Commentary, C.H. Beck - Nomos, München, 2020, pp. 405 urm. şi p. 409; mai detaliat, v. M.J. Schermaier, Historisch-kritischer Kommentar zum BGB, V. II, Schuldrecht: Allgemeiner Teil, 1 Teilband, $\S \S$ 241-304, Mohr Siebeck, Tübingen, 2007, pp. 1032 urm. şi mai ales pp. 1179 urm.).

${ }^{41}$ Art. 1082 V. C.civ.: „Debitorul este osândit, de se cuvine, la plata de daune-interese sau pentru neexecutarea obligației, sau pentru întârzierea executării, cu toate că nu este reacredință din parte-i, afară numai dacă nu va justifica că neexecutarea provine din o cauză străină, care nu-i poate fi imputată". Optica era întărită de art. 1083 V.C.civ. care indica expres exonerarea de răspundere în cazul forței majore. Optica vremii era în sensul că vinovăția este un principiu al răspunderii, că vinovăţia este prezumată în materie contractuală şi că prezumția ar putea fi înlăturată prin probarea imposibilității fortuite [D. Alexandresco, op.cit. Explicațiunea teoretică şi practică a dreptului civil român, T. V, Obligațiile (I), Tipografia Națională, Iaşi, 1898, p. 504: „(...) pentru că dacă este de principiu că culpa delictuală sau aquiliană nu se presupune; din contră, de câte ori o obligație naşte din contract (...), debitorul trebuie să justifice liberațiunea sa, ceea ce la caz de neexecutarea obligațiunei, lasă a se presupune o culpă, până la dovedirea casului fortuit, dovadă ce trebuie să se facă de debitorul care se pretinde liberat (...)"]; M. Cantacuzino, Elementele dreptului civil, All Educational, Bucureşți, 1998, p. 429; oarecum în sensul prezumării culpei contractuale ca efect al neexecutării, v. C. Hamangiu, I. Rosetti-Bălănescu, A. Băicoianu, Tratat de drept civil, V. 2, All, Bucureşti, 1998, p. 541; mai recent, în sensul unei răspunderi contractuale bazate eminamente pe culpă, dar şi în sensul indirect al prezumării culpei contractuale, $v$. C. Stătescu, C. Bîrsan, Teoria generală a obligațiilor, Hamangiu, Bucureșți, 2008, p. 332; este de înțeles că lucrările citate se referă, în realitate, la toate remediile pentru neexecutare). Adde, C. Oprişan, Sancţiunea în dreptul civil român. O posibilă sinteză, în RRD nr. 11/1982, pp. 20 urm.; M. Costin, Contribuţii la studiul sancţiunii juridice, în SCJ, 1978, nr. 2, pp. 146 urm.; M. Mureşan, D. Chirică, Contribuţii la studiul conceptului de sancţiune civilă (I), în „Studii de drept privat”, Universul Juridic, Bucureşti, 2010, pp. 70 urm. (v., în special, pp. 75 urm., pp. 78 urm.). 
continuarea unei tradiții doctrinare şi jurisprudențiale româneşti ${ }^{42}$ că una din condițiile substanțiale ale rezoluțiunii este vinovăția43. Unul din argumentele centrale ale acestei teze (exprimat explicit sau implicit) este acela că toate condițiile prevăzute de art. 1.516 alin. (2) C.civ. pentru activarea remediilor sunt pe deplin aplicabile şi în materia rezoluțiunii dacă nu se prevede altfel. In mare, ideea este aceea că remediile la care se referă art. 1.516 C.civ. nu sunt aplicabile decât în ipotezele în care avem de a face cu neexecutări nejustificate culpabile. Pentru toate celelalte ipoteze, remediile ar fi aplicabile numai printr-un mecanism analogic dacă legiuitorul permite analogia. Pe de altă parte, în această teză, imposibilitatea fortuită de executare constituie o ipoteză cu un regim aparte pentru care s-ar aplica doar anumite reguli în materia remediilor dacă legiuitorul prevede 44 . In acest din urmă caz, remediile pentru neexecutare nu ar fi aplicabile, se spune, deoarece potrivit art. 1.557 alin. (1) C.civ. desființarea contractului se produce cu titlu automat, adică de plin drept, din chiar momentul producerii evenimentului care generează imposibilitatea. Prin urmare, nu poate fi vorba de aplicarea vreunor remedii

${ }^{42}$ Vinovăția în materia rezoluțiunii era regula comună în V.C.civ. V., de pildă: C. Hamangiu, I. Rosetti-Bălănescu, A. Băicoianu, Tratat de drept civil român, V. 2, All, Bucureşți, 1998, p. 539; T.R. Popescu, P. Anca, Teoria generală a obligațiilor, Ed. Stiințifică, Bucureşti, 1968, p. 138; D. Cosma, Teoria generală a actului juridic civil, Ed. Stiințifică, Bucureșți, 1969, p. 432; C. Stătescu, C. Bîrsan, Drept civil. Teoria generală a obligațiilor, All Educational, Bucureșți, 1988, p. 86, nr. 75; L. Pop, Teoria generală a obligațiilor, Lumina Lex, Bucureşți, 2000, p. 78; V. Stoica, Rezoluțiunea şî rezilierea contractelor civile, All, Bucureșţi, 1997, p. 55. Jurisprudența era în acelaşi sens (v., de pildă, C.S.J., s. civ., dec. nr. 824/1999, în Dreptul nr. 12/2003, p. 228; I.C.C.J, s. civ., dec. nr. 536/2005, în Dreptul nr. 5/2006, p. 269).

${ }^{43}$ V. supra, autorii indicați la notele nr. 39, 30.

44 Optica este puternic înrădăcinată într-o schemă de comentare a V.C.civ. care includea în noțiunea de „efecte specifice ale contractelor sinalagmatice” teoria riscurilor care la rândul ei includea imposibilitatea fortuită de executare. Pentru aceasta exista o reticență majoră în aplicarea remediilor comune pentru orice neexecutare (e.g. C. Stătescu, C. Bîrsan, op.cit., pp. 83 urm.). 
pentru neexecutare. Prin excepţie, dacă evenimentul fortuit atrage o imposibilitate temporară de executare, s-ar putea aplica regulile rezoluțiunii, „în mod corespunzător”, dar nu ar fi vorba de o rezoluțiune propriu-zisă. Oare este această interpretare convergentă cu linia actualei reglementări ? Credem că ea constituie o interpretare mai degrabă „literală” a textelor şi că evită formularea vreunei reguli care să jeneze ansamblul tezei aşa cum exista ea înainte de intrarea în vigoare a noului cod. Dar mai credem şi că, în cele din urmă, relevanța practică a împărtăşirii acestei opinii sau celei opuse este şi ea redusă.

22. In aceeaşi teză, în mod curios, se susține însă că, în interpretarea art. 1.530 C.civ., vinovăția nu ar fi o cauză absolută a remediului daunelorinterese, invocându-se formularea textului legal care alătură neexecutării fără justificare şi formula „după caz, culpabile a obligației” 45 . Se susține astfel că daunele-interese ar putea fi acordate în ipoteza unei neexecutări fără justificare culpabile sau chiar şi neculpabile ${ }^{46}$. In ce priveşte neexecutarea fără justificare şi neculpabilă chiar şi ea ar putea justifica angajarea unei răspunderi contractuale ${ }^{47}$, ipoteze în care ar fi vorba de o răspundere contractuală obiectivă ${ }^{4}$. $\mathrm{O}$ asemenea interpretare dă o oarecare justificare formulării curioase a art. 1.530 C.civ. care ne sugerează mai degrabă o eroare de redactare decât o alegere rațională a legiuitorului. Trebuie însă să reținem că există o oarecare justificare suplimentară pentru această optică şi că că ea se întemeiază pe existența obligațiilor de garanție [art. 1.695 urm. C.civ. şi art.

\footnotetext{
${ }^{45}$ V. V. Stoica, art. precit. - Ințelesul noțiunilor de rezoluțiune şi reziliere în Codul civil român. Intre dezideratul clarității şi fatalitatea ambiguităţii, nota nr. 16.

${ }^{46}$ Ptr. această distincție, $v$. F. A. Baias, V. Cîlțea, art. precit., pp. 682 urm.

${ }^{47}$ V. V. Diaconiță, op.cit., p. 90 (autorul nefiind, de altfel, un partizan al tezei tradiționaliste în materia remediilor).

${ }^{48}$ V. F. A. Baias, V. Cîlțea, op.cit., p. 684
} 
1.707 urm. C.civ.], despre care se susţine chiar şi în dreptul comparat că am avea de a face cu o formă de răspundere obiectivă49. Un alt exemplu îl constituie obligația care are ca obiect bunuri de gen pentru a căror neexecutare imposibilitatea fortuită nu constituie o justificare [art. 1.636 alin. (6) C.civ.].

23. In sinteză, am putea susține că deficiențele tezei subiective sunt următoarele: (i) nu rezolvă într-o formulă unitară la nivelul remediilor, toate formele de neexecutare a contractului (culpabile sau neculpabile, deopotrivă); (ii) pentru acest motiv, nu oferă un răspuns ferm cu privire la tratamentul imposibilității fortuite de executare; (iii) nu poate prezenta o explicaţie bazată pe vinovăție acolo unde este vorba de aplicarea remediilor la neexecutarea obligațiilor având ca obiect bunuri de gen; (iv) nu poate prezenta o explicaţie bazată pe aceeaşi vinovăție pentru aplicarea remediilor la obligațiile de garanție, în special contra viciilor ascunse şi evicțiunii în ipotezele în care vânzătorul (înstrăinătorul) este inocent; (v) în pofida subiectivismului său, această teză pledează, uneori, pentru daune-interese „obiective” neconsiderând eronată alăturarea nejustificării şi vinovăției în formularea art. 1.530 C.civ.

VII. Opinia „utilitaristă” şi contradicțiile sale interne

24. Legitățile sistemului remediilor. In această opinie, aflată într-o aparentă opoziție cu teza tradițională50, se susține că interpretarea care

${ }^{49}$ V. G.H. Treitel, op.cit. - Remedies for Breach of Contract, pp. 10 urm.; F. Ranieri, op.cit. Europäisches Obligationenrecht, pp. 708 urm. (pentru aşa-zisul model preluat din common law).

${ }^{50}$ V. supra, secțiunea V.

\section{6}


trebuie dată art. 1.516 alin. (2) C.civ. este parțial diferită. In sinteză, legitățile remediilor ar fi următoarele: (i) remediile pot fi activate de îndată ce există o neexecutare; (ii) toate remediile pot fi activate în cazul neexecutării fără justificare (cu referire specială la executarea în natură, excepția de neexecutare, rezoluțiune şi daune-interese - i. e. toate remediile sunt aplicabile pentru neexecutarea cu vinovăție); (iv) toate remediile, cu excepția daunelor-interese şi executării silite în natură, sunt aplicabile neexecutării cauzate fortuit; (iv) în particular, se susține că rezoluțiunea poate fi invocată cu succes şi în cazul neexecutărilor neculpabile51.

${ }^{51}$ In nuce, teza era prezentă în dreptul românesc încă înainte de intrarea în vigoare a Codului civil. V., în special, D. Alexandresco, Dreptul civil român în comparațiune cu legile vechi şi cu principalele legislațiuni străine, T. VI, Despre obligațiuni, Tipografia Națională, Iaşi, 1900, p. 84 (în sensul aplicării rezoluțiunii şi la ipotezele de neexecutare cauzată de caz fortuit sau forță majoră); L. Pop, Tratat de drept civil. Obligațiile, V. II, Contractul, Universul Juridic, Bucureşti, 2009, pp. 734 urm., nr. 296 [în sensul că singura condiție absolut necesară ptr. a se putea invoca rezoluțiunea este „neexecutarea ilicită a obligațiilor contractuale de către debitor, indiferent dacă neexecutarea este sau nu culpabilă” (ibidem, p. 735)]; după intrarea în vigoare a Codului civil, $v$., în acelaşi sens, I.F. Popa, în L. Pop, I.F. Popa, S. I. Vidu, Curs de drept civil. Obligațiile, Universul Juridic, Bucureşti, 2015, pp. 180 urm. (unde am încercat să articulăm o teorie generală „obiectivă” a remediilor); P. Vasilescu, Obligaţiile, Hamangiu, Bucureşti, 2017, p. 535 [despre rezoluțiune fără vinovăție, deşi la nota nr. 1 se trimite la noțiunea de neexecutare imputabilă debitorului; dar $v$. în general, despre remedii, p. 526, unde se constată declinul condiției vinovăției în materie, deși remediile sunt numite „sancțiuni ale neexecutării contractului"; $v$. şi p. 531, în sensul aplicării regulilor rezoluțiunii în cazul imposibilității fortuite temporare de executare]; G. A. Ilie, Riscurile în contracte. De la vechiul la noul Cod civil, Universul Juridic, Bucureşti, 2012, pp. 84 urm.; pp. 496 urm. (atât pentru vechea, cât şi pentru noua reglementare, remediile şi mai cu seamă rezoluțiunea, se aplică şi imposibilităților fortuite de executare a contractelor sinalagmatice); C. Popa, A. Lisievici, Rezoluţiunea în Noul Cod civil (I), în RRDA nr. 8/2012, p. 43; V. Diaconiță, op.cit., pp. 131 urm. (în special, pp. 134135); C. Paziuc, op.cit., pp. 101 urm. (ideea aşteptării legitime ca măsură a remediului rezoluțiunii indică detaşarea autorului de orice condiție a culpei debitorului pentru invocarea acestui remediu); N. Daghie, op.cit., p. 182 (deşi nu este limpede dacă autoarea nu înțelege cumva să califice rezoluțiunea ca o formă de răspundere contractuală, caz în care condiția culpei ar fi necesară). 
25. Locul vinovăţiei. In acest context, principiul este cel conform căruia vinovăția este doar un element posibil al definiției neexecutării contractuale, dar nu este o condiție a activării remediilor. Altfel spus, vinovăția, spre deosebire de optica tradițională, nu este nicidecum o condiție a remediilor, ci doar o cerință a abaterii contractuale pe care o numim neexecutare ${ }^{52}$. Putem spune că vinovăția ne oferă o încălcare a contractului care se include în conceptul larg de neexecutare. $\mathrm{Cu}$ alte cuvinte, încălcarea este specia, în timp ce neexecutarea este genul. Intr-o anumită măsură, această distincție oglindeşte distincția uneori reținută în dreptul comparat între breach of contract şi non-performance of contract.

26. Neexecutarea nejustificată nu înseamnă neapărat neexecutare culpabilă decât în privința remediului daunelor-interese. In acest caz, textul art. 1.530 C.civ., astfel cum s-a arătat în doctrină, este „nefericit” formulat 53 . De fapt, daunele-interese sunt remediul pentru care teza face excepție de la regula obiectivă şi apreciază că vinovăția ar trebui să fie o condiție absolută54. Tot exceptată de la regula obiectivă este uneori executarea silită în natură: în măsura în care imposibilitatea fortuită duce la o imposibilitate de executare în natură, remediul este inaplicabil.

27. Probabil că, în opinia susţinătorilor tezei obiective, textul art. 1.530 C.civ. ar fi trebuit formulat diferit, în sensul că daunele-interese sunt aplicabile atunci când avem de a face cu o neexecutare comisă cu vinovăție şi,

\footnotetext{
${ }^{52}$ V. G.H. Treitel, op.cit., p. 9; B. Nicholas, Fault and Breach of Contract, în J. Beatson, D. Friedmann, Good Faith and Fault in Contract Law, pp. 337 urm.

${ }^{53}$ V. V. Stoica, V. Stoica, art. precit. - Ințelesul noțiunilor de rezoluțiune şi reziliere în Codul civil român. Intre dezideratul clarităţii şi fatalitatea ambiguităţii, nota nr. 16; C. Paziuc, op.cit., pp. 377 urm. [unde autorul construieşte o întreagă teorie în vederea interpretării coerente a art. 1.530 C.civ., folosindu-se de noțiuni precum „culpa obiectivă” (imputabilitate obiectivă) şi „culpa subiectivă” (imputabilitate subiectivă)].

${ }^{54}$ V. I.F. Popa, în L. Pop, I.F. Popa, S.I. Vidu, op.cit., p. 239, nr. 153.
}

\section{8}


cu titlu de excepție, atunci când legea prevede expres, ele ar putea fi aplicate şi unei neexecutări nejustificate, dar neculpabile. Pe cât de tradițional e principiul vinovăției în materie de răspundere contractuală, pe atât de tradiționale sunt şi excepțiile de la acesta, adică acele cazuri în care răspunderea contractuală are un caracter obiectiv. Este din nou vorba de obligația care are ca obiect bunuri de gen [art. 1.634 alin. (6) C.civ.], de obligațiile de garanție [în special contra evicțiunii (art. 1.695 urm. C.civ.) şi contra viciilor ascunse (art. 1.707 urm. C.civ.), dar nu numai]. In ultimele două cazuri, răspunderea contractuală este, în realitate, limitată la interesul restituiriij5 în caz de rezoluțiune pentru cauze de evicțiune sau pentru vicii ascunse făă viclenie (i.e. fără intenție, eventual chiar fără vinovăție) şi devine o răspundere agravată (acoperind şi interesul executării sau pe cel al aşteptării legitime a creditorului) dacă viciile sau cauza de evicțiune au fost ascunse intenționat (i.e. vinovat, cu rea-credință, cu intenție). In ultimele două cazuri, dacă lipseşte vinovăția, observăm că tratamentul este, în realitate, simetric celui al imposibilităţii fortuite de executare în cazul căreia, desființarea automată a contractului atrage restituirea reciprocă a prestațiilor părților.

28. Vinovăția văzută punctual. In materia rezoluțiunii, această opinie este insistent împotriva reținerii condiției vinovăției pentru activarea

\footnotetext{
${ }^{55}$ V. I.F. Popa, Coordonatele răspunderii contractuale (I), în RRDP nr. 5/2015, pp. 156 urm., nr. 12; C. Paziuc, Interesul ocrotit prin daunele-interese contractuale şi calculul daunelorinterese, în M. Nicolae, R. Rizoiu, L. Toma-Dăuceanu, op.cit., pp. 690 urm. Practic, limita daunelor-interese subsecvente desființării unui contract pentru evicțiune sau vicii ascunse în cazurile în care vânzătorul a fost de bună-credință (înțelegem, în principiu, că a acționat fără vinovăție), se rezumă la restituirea unei plăți considerate retroactiv ca nedatorate. In acest sens sunt formulate art. 1.702 C.civ. [care este adevărat că include o excepție inexplicabilă de la regula, la alin. (1) lit. a) incluzând în sfera daunelor-interese şi „,pierderile suferite şi câş̧tigurile nerealizate de către cumpărător din cauza evicțiunii”] şi mai ales art. 1.712 alin. (2) C.civ. [care nu cuprinde nicio abatere de la regula restituirii].
} 
remediului ${ }^{56}$ sau mai bine zis pentru indiferența vinovăției în invocarea rezoluțiunii. Raționamentul se bazează tot pe textul art. 1.516 alin. (2) C.civ., dar şi pe existența în capitolul dedicat remediilor a imposibilității fortuite de neexecutare supusă uneori aceloraşi remedii. In esență: rezoluțiunea poate fi invocată dacă neexecutarea este suficient de importantă şi nejustificată. Justificările ar fi excepția de neexecutare sau imposibilitatea fortuită. Si totuşi, pentru ultima, ori se desființează automat contractul, ori se aplică remediile. Prin urmare, de ce să reținem vinovăţia ca şi condiție ? Argumentele colaterale sunt şi ele numeroase. Se invocă, în special garanția contra viciilor ascunse şi cea contra evicțiunii, ipoteze în care este de notorietate că vinovăția nu este o condiție a invocării rezoluțiunii.

29. Contradicții. Si această teză are limitele sale explicative. Intre altele: (i) nu poate oferi o explicație logică pentru daunele-interese acordate în cazul neexecutării obligațiilor purtând asupra bunurilor de gen; (ii) nu poate oferi decât cu prețul unor ficțiuni juridice o interpretare coerentă a art. 1.530 C.civ.; (iii) nu ține seama de formularea art. 1.557 alin. (2) C.civ. care trimite prin analogie doar la remediul rezoluţiunii în caz de imposibilitate fortuită temporară; (iv) nu conferă art. 1.516 C.civ. statutul de text unic, de fond, privind condițiile aplicării remediilor.

VIII. Schema de interpretare logică a textelor legale

3o. Contradicțiile legale. Din păcate, în privința interpretării textelor legale aferente remediilor, trebuie să admitem că acestea nu au o coerență logică desăvârşită. Astfel, nu putem să nu observăm cel puțin două

\footnotetext{
${ }^{56}$ V. supra nota nr. 47.
}

\section{0}


uşoare contradicții care există între textele aferente remediilor. Prima: între formularea art. 1.516 alin. (2) C.civ. 57 şi cea a art. 1.530 C.civ. Primul text admite că neexecutarea fără justificare permite aplicarea remediilor, în timp ce al doilea adaugă la condiția enunțată şi formula "(...) sau, după caz, culpabile a obligației.". A doua: între formularea art. 1.530 C.civ. (care sugerează posibilitatea acordării daunelor-interese şi în ipotezele în care debitorul nu este vinovat de neexecutare, alături de cele în care neexecutarea este "vinovată") şi art. 1.547 C.civ. (care prevede că debitorul este ținut să repare prejudiciul cauzat cu intenție sau din culpă, adică, în ambele cazuri, cu vinovăţie).

31. Concilierea textelor. Este oare posibilă o conciliere a contradicțiilor de mai sus ? Credem că răspunsul este afirmativ. Soluția de compromis presupune o îmbinare a teoriei tradiționale cu cea „utilitaristă” 58 referitoare la remedii. Cel puțin două metode de interpretare a textelor legale ne îndreaptă spre o soluție rezonabilă de conciliere în materia supusă atenției.

32. Interpretarea restauratoare. Aşa-numita retrieving interpretation 59 este metoda care pretinde o restaurare a sensului originar, dorit de legiuitor, cu privire la textul supus interpretării. Pentru aplicarea metodei este necesară verificarea a ceea ce în teoria interpretării juridice se cheamă drafting history. De aceea, suntem obligați să facem un retur

\footnotetext{
${ }^{57}$ Despre care putem spune că este dublat de art. 1.350 alin. (2) C.civ. care oferă o definiție a răspunderii contractuale concurentă celei din art. 1.530 C.civ., ambele referindu-se la „neexecutarea fără justificare” a obligațiilor.

${ }^{58}$ Calificarea îi aparține prof. M. Nicolae (v. M. Nicolae, art. precit. - Natura juridică a „remediilor” (sancțiunilor) contractuale, p. 612-613.

59 Pentru care, $v$. J. Raz, Interpretation Without Retrieval, în A. Marmor (ed.), Law and Interpretation. Essays in Legal Philosophy, Clarendon Press, Oxford, 1997, p. 155 urm. (deşi autorul militează împotriva acestei metode de interpretare este limpede că o consideră cea mai la îndemână pentru juristul de astăzi).
} 
cronologic şi comparat la sursele textelor legale în discuție. Primul şi cel mai important text, art. 1.516 alin. (2) C.civ. îşi are sursa în art. 1590 alin. (2) C.civ. Quèbec $^{60}$ pe care îl reproduce. Sensul acestui text este acela că accesul la remediile pentru neexecutare este deschis de o neexecutare ilicită, adică lipsită de justificare. Justificările, adică acele situații care fac ca neexecutarea să aibă un caracter licit sunt parțial indicate de art. 1.555-1.557 C.civ. (ordinea executării prestațiilor, excepția de neexecutare şi imposibilitatea fortuită de executare). Parțial, deoarece există şi alte cazuri care pot face ca o neexecutare să aibă un caracter licit (de pildă, neexecutarea imputabilă creditorului, fără ca fapta creditorului să constituie neapărat o ipoteză de imposibilitate fortuită pentru debitor - art. 1.517 C.civ.; poate fi vorba chiar de prescripție care şi ea poate constitui o justificare; s-a susținut că şi compensația legală poate avea caracterul unei justificări a neexecutării $\left.{ }^{61}\right)$. Cu toate acestea, textul art. 1.516 alin. (2) C.civ. nu prevede nicidecum că remediile menționate în text se pot aplica numai în cazurile de neexecutare fără justificare a obligațiilor. Prin urmare, formularea sa actuală admite că este posibilă aplicarea remediilor şi pentru alte neexecutări. In cadrul acestor neexecutări putem include neexecutarea cauzată fortuit [art. 1.557 alin. (2) C.civ.] sau neexecutarea fără

\footnotetext{
${ }^{60}$ Art. 1590 alin. (2) C.civ. Québec începe cu această formulare: "Lorsque le débiteur, sans justification, pas son obligation et qu'il est en demeure, le créancier peut, sans préjudice de son droit à l'exécution par équivalent de tout ou partie de l'obligation: (...)". Ptr. Explicații, $v$. M. Nicolae, art. precit. - Natura juridică a „remediilor” (sancțiunilor) contractuale, p. 584 urm.; V. Diaconiță, op.cit., p. 61 urm.; F. A. Baias, V. Cîlțea, art. precit., p. 680 urm.

${ }^{61} V$. Sunt calificate ca „neexecutări legitime ale obligațiilor”, de pildă, confuziunea şi remiterea de datorie ( $v$. D. Lluelles, B. Moore, Droit des obligations, 3e éd., Thémis, Montréal, 2018, pp. 1671 urm.). In acelaşi sens, despre compensație, $v$. A. Buciuman, La compensation justification de non-exécution, în A-R. Trandafir, M. D. Bob, Inexécution et justifications. Le pouvoir actuel d'expression du droit continental, Universul Juridic, Bucureşti, 2019, p. 107 urm.
}

\section{2}


vinovăție a obligațiilor având ca obiect bunuri de gen [art. 1.634 alin. (6) C.civ.].

33. Formularea prezentă în art. 1590 C.civ. Québec (aparent de „drept nou”) poate fi analizată şi în raport cu utilizarea vinovăției în sistemele de drept despre care se spune că pun în practică teza obiectivă în materia remediilor. Vom observa, la o atentă comparație, că între cele două formule juridice de aplicare a remediilor nu există un clivaj real. Intre altele, § 314 din first Restatement of Contract Law ${ }^{62}$ insistă asupra elementului vinovăție în definirea noțiunii de „breach of contract”. In plus, în nota aferentă Capitolului 11 din Restatement 2d of Contracts, se afirmă „Contract liability is strict liability (...). The obligor is therefore liable in damages for breach of contract even if he is without fault (...)”. In dreptul anglo-american, lipsa justificării este doar un element al definiției neexecutării şi al calificării acesteia. Cu toate acestea, chiar şi într-un asemenea sistem, obiectivismul absolut ar însemna lipsa cauzelor care exonerează de răspundere contractuală. Or, în toate aceste sisteme de common law, răspunderea nu poate fi angajată (daunele-interese nu pot fi acordate) în cazul în care neexecutarea este scuzată de o ipoteză de forță majoră. De pildă, sistemul american invocat, recunoaşte în § 261 din $2 d$ Restatement of Contracts dreptul la neexecutare al persoanei obligate în cazul unei imposibilități fortuite survenite (supervinning impracticability). Astfel cum s-a arătat, puntea între sistemele obiectiviste şi cele subiectiviste este

\footnotetext{
${ }^{62} \S 314$ First Restatement of Contract Law: „A failure, without justification, to perform all or any part of what is promised in a contract is a breach thereof." Se consideră că textul subliniază că exigența vinovăției vizează definiția neexecutării contractuale şi nu condiționarea remediilor (v. G.H. Treitel, op.cit., p. 8). Desigur că, această formulare nu este nici ea neapărat originală. Aceeaşi idee e inspirată însă şi de vechiul art. 1147 C.civ. fr. care utilizează şi el formula „ne justifie pas que l'inexécution (...)". Am spune, în terminologia common law că definițiile de mai sus permit stabilirea unei distincţii între non-performance şi breach $(v$. J. Kleinschmidt, în N. Jansen, R. Zimmermann, op.cit., p. 1080, nr. 13).
}

\section{3}


dată de cuplul antagonic vinovăţie/forță majoră63. Ducând mai departe ideea, se poate susţine că nici măcar nu există un sistem al remediilor integral obiectiv 64 .

34. Concluzia este aceea că sensul originar al art. 1.516 alin. (2) C.civ. nu vizează vinovăția ca şi condiție generală de aplicare a tuturor remediilor, dar nici nu o exclude. Mai degrabă, articolul citat se serveşte de ea în crearea unui anumit tip de abateri contractuale - neexecutările nejustificate culpabile $^{65}$. Dar putem identifica şi ipoteze de neexecutare nejustificată neculpabile admise de toate sistemele în materie de remedii (obligațiile de plată a unor sume de bani, de predare a unor bunuri de gen, respectiv obligațiile de garanție) pentru care se admite angajarea obiectivă a răspunderii contractuale. Dacă este aşa, înseamnă că vinovăţia va putea fi considerată condiție a aplicării unui remediu doar dacă este indicată expres de legiuitor în reglementarea individuală a remediilor. Că acesta este sensul acordat de legiuitorul român şi că intenția sa nu este totalmente identică celei a legiuitorului canadian, ne este probată de existența art. 1.557 alin. (2) C.civ.,

${ }^{63}$ V. G.H. Treitel, Frustration and Force Majeure, Sweet \& Maxwell, Londra, 2014, pp. 5 urm. Până şi în faimoasa doctrină a contractelor absolute, fundamentată de cazurile Paradine $v$. Jane (1647) şi Taylor v. Caldwell (1863), interpretarea oferită de doctrina de common law în zilele noastre este în sensul că absolutismul contractului poate fi înfrânt de forța majoră (idem, pp. 20 urm.). Despre cea de a doua cauză, v. B. Nicholas, art. precit., pp. 346 urm.; G.H. Treitel, op.cit. - Frustration and Force Majeure, pp. 40 urm.

${ }^{64}$ Până şi Convenția de la Viena privind vânzarea internațională de mărfuri (1980) despre care se spune că instaurează un sistem eminamente obiectiv în materie de remedii şi care deliberat omite condiția vinovăției în reglementarea pe care o oferă daunelor-interese (art. 74-77), are grijă să reglementeze şi două excepții pentru întregul sistem al remediilor: impedimentul în executare care este dincolo de controlul părții ținută la executare (art. 79) şi neexecutarea cauzată de fapta celeilalte părți (art. 80). Pentru tematică, $v$. I. Schwenzer, în I. Schwenzer, Commentary on the UN Convention on the International Sale of Goods (CISG), $4^{\text {th }}$ ed., Oxford, 2016, pp. 1057 urm.

${ }^{65}$ Ptr. Identificarea categoriei în dreptul nostru, v. F. A. Baias, V. Cîlțea, art. precit., p. 682 urm.

\section{4}


un paragraf inspirat, nu din modelul canadian ${ }^{66}$, ci din art. 7.1.7 par. (2) al Principiilor UNIDROIT, respectiv din art. 8:108 par. (2) PDEC $^{67}$ şi art. III.3:104 par. (3) DCFR, toate aceste texte fiind înclinate spre ideea aplicării remediilor pentru neexecutare ipotezelor de imposibilitate temporară fortuită de executare ${ }^{68}$.

35. Chestiunea vinovăției ține într-o mare măsură de factualismul şi diversitatea remediilor. Reconcilierea art. 1.530 C.civ. cu celelalte texte (art. 1.350, 1.516 şi mai ales, art. 1547 C.civ.) poate fi înțeleasă în această cheie: daunele-interese sunt virtual aplicabile neexecutării fără justificare culpabile (majoritatea abaterilor contractuale) şi, prin excepție, şi unor neexecutări fără justificare neculpabile (obligațiile având ca obiect bunuri de gen şi obligațiile de garanție). Tot în chip de concluzie, trebuie să reținem că art. 1.516 alin. (2) C.civ. nu este atât de diferit de rudele sale din common law şi că, în realitate, reglementarea cauzelor care îl exonerează de răspundere pe debitor sunt o probă că prezumarea culpei sale este regula în materia remediilor (regulăcondiție pentru teoria subiectivă; regulă-punct de plecare în teoria obiectivă a remediilor $)^{69}$.

\footnotetext{
${ }^{66} V$. formularea art. 1470 C.civ. Québec care nu se regăseşte decât în paragraful (1) al art. 1.557 C.civ. român.

${ }^{67}$ Probabil că art. 8:108 PDEC (identic în formulare cu art. III.-3:104 DCFR) constituie textul de inspirație pentru legiuitorul român: Where the impediment is only temporary the excuse provided by this Article has effect for the period during which the impediment exists. However, if the delay amounts to a fundamental non-performance, the creditor may treat it as such.

${ }^{68}$ In sinteză, v. T. Rüfner, în N. Jansen, R. Zimmermann (ed.), op.cit., p. 1165 nr. 1 şi pp. 1173 urm., nr. 17 urm.

${ }^{69}$ Pentru nivelul general al acestei observații (i.e. că nu există o discrepanță atât de mare cum pare la prima vedere între sistemele de remedii din dreptul continental şi cel de common law sau între sitemele subiectiviste şi cele obiectiviste), $v$. G.H. Treitel, op.cit. - Remedies for Breach of Contract. A Comparative Account, pp. 7 urm.; B. Nicholas, art. precit., pp. 337 urm.
}

\section{5}


36. Interpretarea constructivă. $O$ a doua interpretare este cea constructivă. Este vorba de o interpetare a textelor legale menită să ne permită o soluție funcțională de utilizare a acestora ${ }^{70}$. Vom putea observa, în acest context că, în general, vinovăția este, de principiu, o condiție nerelevantă prin prisma textelor dedicate remediilor (această concluzie este întărită şi de interpretarea unei jurisprudențe care repetă sub forma unui automatism definiții tradiționale fără să ne convingă că mai crede în ele). Prin excepție, vom putea observa că vinovăția este particular importantă pentru definirea unui anumit tip de neexecutare căreia i se aplică un anumit set de remedii, mai extins decât cel aplicabil neexecutărilor neculpabile. Premisa logicojuridică de la care pornim este următoarea: „Remediile disponibile pentru neexecutarea unei obligații depind de faptul că neexecutarea nu este justificată, este justificată de un impediment sau rezultă din comportamentul celeilalte părți. Această sumă de reguli reprezintă dreptul comun al normelor Statelor membre, chiar dacă acestea ajung la aproximativ aceleaşi rezultate

\footnotetext{
${ }^{70}$ Ea porneşte de la ideea unității sistemului remediilor şi de la presupoziția că remediile constituie o parte integrantă a drepturilor legal recunoscute şi ocrotite ( $v$. D. Friedmann, Rights and Remedies, în N. Cohen, E. McKendrick (eds.), Comparative Remedies for Breach of Contract, Hart, Oxford/Portland, 2005, pp. 3 urm. (în special, pp. 10 urm.).
} 
prin intermediul unor structuri conceptuale diferite" ${ }^{71}$. In aplicarea acestei metode, este important să observăm următoarele ${ }^{22}$ :

\section{a) art. 1.516 alin. (2) C.civ. face pereche, în principal, cu art.}

1.557 C.civ. şi, în secundar, cu celelalte cazuri de justificare legală a neexecutării. De îndată ce debitorul unei obligații contractuale nu execută prestația la care s-a îndatorat, treỉzs soluțiii sunt posibile:

(i) neexecutarea este nejustificată [neexecutarea îi este imputabilă debitorului -neexecutare fără justificare imputabilă] - caz în care se vor putea aplica toate remediile pentru neexecutare, în funcţie de adecvarea lor ${ }^{74}$, ierarhia lor legală ${ }^{75}$ şi alegerea creditorului ${ }^{6}$. Creditorul va avea dreptul să aleagă, în funcție de gravitatea neexecutării şi respectând ierarhia legală a

${ }^{71}$ V. C. von Bar, E. Clive (eds.), op.cit. - DCFR. Full Edition, V. I, p. 772. Cele trei reguli sunt sintetizate, probabil în cea mai modernă formulă de aplicare a remediilor, în art. III.-3:101 DCFR (Remedies available): (1) If an obligation is not performed by the debtor and the nonperformance is not excused, the creditor may resort to any of the remedies set out in this Chapter. (2) If the debtor's non-performance is excused, the creditor may resort to any of those remedies except enforcing specific performance and damages. (3) The creditor may not resort to any of those remedies to the extent that the creditor caused the debtor's nonperformance."

72 Tendința „utilitaristă” este totuşi manifestă în această interpretare (v. J. Kleinschmidt, în N. Jansen, R. Zimmermann, op.cit., p. 1083 urm.; pentru schema de interpretare comună, $v$. p. 1090, nr. 1).

${ }^{73}$ Indeobşte, în dreptul de origine al textelor noastre (dr. quebecoaz) se vorbeşte doar de primele două cazuri pe care le vom prezenta după formula: dacă neexecutarea nu este imputabilă debitorului, atunci se aplică teoria riscurilor $(v$. J-L. Baudouin, P.-G. Jobin, N. Vézina, Le obligations, 7e éd., Yvon Blais - Thomson Reuters, Cowansville, p. 1064, nr. 854; V. Karim, Les obligations, V. 2, Articles 1497 à 1707, 4e éd., Wilson \& Lafleur, Montréal, 2015, p. 519, nr. 1384; mai amplu, $v$. D. Lluelles, B. Moore, op.cit., pp. 1707 urm., în special, nr. 2747 urm.).

${ }^{74}$ Pentru fiecare neexecutare există un remediu adecvat (I.F. Popa, în L. Pop, I.F. Popa, S.I. Vidu, op.cit., p. 183, nr. 120 B).

${ }^{75} \mathrm{O}$ ierarhie legală cristalizată în jurul principiului favor contractus (idem, p. 185, nr.. $120 \mathrm{C}$ ).

${ }^{76}$ In limitele respectării ierarhiei legale, creditorul are posibilitatea alegerii între remediile disponibile (idem, p. 187, nr. $120 \mathrm{E}$ ).

\section{7}


remediilor, între acordarea unui termen de executare (art. 1.521-1.526 C.civ.), $\begin{array}{lllll}\text { executarea in natură (art. } & 1.527-1.529 & \text { C.civ.), }\end{array}$ rezoluțiunea/rezilierea/reducerea propriilor prestații (art. 1.549-1.554 C.civ.), excepția de neexecutare (art. 1.556 C.civ.) cumulabile toate cu dauneleinterese (art. 1.530-1.548 C.civ.). In acest caz remediile se aplică pentru o neexecutare comisă cu vinovăție adică pentru o încălcare a contractului;

(ii) neexecutarea este justificată de o imposibilitate fortuită [nu îi este imputabilă debitorului, pentru că avem de a face cu o imposibilitate fortuită de executare - neexecutare justificată fortuită] $]^{77}$ - caz în care, se va aplica teoria riscurilor care poate să includă sistemul remediilor sau nu. Astfel, dacă avem de a face cu o imposibilitate totală şi definitivă de executare [art. 1.557 alin. (1) C.civ.], contractul este desființat de plin drept şi se aplică dreptul restituirii prestațiilor executate (art. 1.635 urm. C.civ.) $)^{78}$. Dacă avem de a face cu o imposibilitate fortuită de executare temporară [art. 1.557 alin. (2) C.civ.]79, se vor aplica toate remediile adecvate, cu excepția celor care nu

\footnotetext{
${ }^{77}$ Având de a face cu una din versiunile „neexecutării licite”. Ptr. această noțiune, v., în special, C. Chabas, L'inexécution licite du contrat, L.G.D.J., Paris, 2002. Sintagma a fost preluată şi în dr. românesc. $V$., în special, L. Pop, op.cit. - Contractul, p. 509 urm., nr. 205; pentru determinarea noțiunii de „neexecutare nejustificată”, în opoziție cu „neexecutarea justificată”, adică licită, $v$. V. Diaconiță, Neexecutarea fără justificare şi neexecutarea culpabilă. Scurt exerciţiu de corelare, în RRDP nr. 1/2015, p. 86 urm.; V. Terzea, Cauze justificate de neexecutare a obligaţiilor contractuale, în RRDP nr. 3/2019, p. 520 urm.

${ }^{78}$ V. A. G. Ilie, op.cit., p. 494 urm.; I.F. Popa, în L. Pop, I.F. Popa, S.I. Vidu, op.cit., pp. 255 urm.; P. Vasilescu, op.cit., p. 531 (unde se vorbeşte, pentru ipoteza imposibilității parțiale fortuite, de o desființare „judiciară” a contractului, soluție cu care nu putem fi de acord); C. Zamşa, în F. A. Baias et alii, op.cit., p. 1765 (unde se vorbeşte de „un caz particular de rezoluțiune" pentru imposibilitatea fortuită parțială de executare).

79 Sunt de adăugat aici şi variantele intermediare: imposibilitate definitivă parțială de executare, imposibilitate temporară totală sau parțială şi orice alte versiuni care nu intră în sfera unei imposibilități absolute şi totale astfel încât pot justifica menținerea interesului creditorului pentru un „rest contractual" care mai poate fi executat ( $v$. I.F. Popa, în L. Pop, I.F. Popa, S.I. Vidu, op.cit., p. 257).
}

\section{8}


sunt compatibile cu lipsa de vinovăție. Aşadar, în acest din urmă caz, sunt virtual aplicabile termenul suplimentar de executare, executarea silită în natură pentru ce a rămas posibil de executat după trecerea evenimentului fortuit, excepția de neexecutare, rezoluțiunea/reducerea prestațiilor/rezilierea (în cazul în care partea rămasă executabilă nu mai prezintă interes pentru creditor) ${ }^{80}$. In ce priveşte daunele-interese, acestea nu vor putea fi solicitate pentru partea prestațiilor contractuale afectate de imposibilitatea fortuită, dar vor putea fi solicitate pentru restul prestaţiilor cărora li se va aplica regimul comun al remediilor dacă creditorul înțelege să persiste în executare; identic, executarea în natură nu va putea fi solicitată pentru partea devenită imposibil de executat. In această situație, avem de a face cu o neexecutare a contractului care nu este şi o încălcare a acestuia;

(iii) neexecutarea este cauzată în tot sau în parte de fapta creditorului - în acest caz, debitorul nu execută, ori pentru că cealaltă parte nu şi-a executat ea însăşi propria prestație şi regula este simultaneitatea executării prestațiilor, ori pentru că cealaltă parte împiedică prin comportamentul său executarea prestațiilor debitorului. In ambele cazuri avem de a face, de cele mai multe ori, cu forme ale mora creditoris care transferă povara sau beneficiul remediilor către cealaltă parte. Prin excepție, poate fi vorba doar de o neexecutare cauzată fără vinovăție de creditor. Ambele situații sunt avute în vedere de art. 1.517 C.civ. (valabil pentru toate remediile) şi art. 1.534 C.civ. (referitor la daunele-interese imputabile creditorului - în acest caz, este însă vorba doar de „acțiunea sau omisiunea sa

\footnotetext{
${ }^{80}$ V. C. von Bar, E. Clive (eds.), op.cit. - DCFR. Full Edition, pp. 785 urm. [formularea art. III.3:104 par. (3) DCFR este extrem de relevantă: (3) Where the excusing impediment is only temporary the excuse has effect for the period during which the impediment exists. However, if the delay amounts to a fundamental non-performance, the creditor may treat it as such.
}

\section{9}


culpabilă”), dar şi de art. 1.556 C.civ. (privitor la excepția de neexecutare). Astfel, dacă debitorul dintr-un contract sinalagmatic este gata să execute, dar este împiedicat de creditor să o facă, creditorul însuşi se pune în ipostaza unui debitor care încalcă contractul (neexecutând o obligație concretă prevăzută contractual sau dacă nu este cazul, cel puțin obligația generală legală de bunăcredință contractuală). In acest caz, debitorul inițial va fi cel îndreptățit la invocarea remediilor pentru neexecutare.

b) Vinovăția este prezumată de neexecutare: "Culpa debitorului unei obligaţii contractuale se prezumă prin simplul fapt al neexecutării" (art. 1.548 C.civ.) ${ }^{81}$. Această regulă este aplicabilă oricărei neexecutări, numai că ea prezintă cu adevărat relevanță doar în privința daunelor-interese. Vom oferi câteva exemple. Dacă avem de a face cu invocarea rezoluțiunii pentru neexecutare, creditorul trebuie, în principiu, să probeze doar neexecutarea suficient de importantă. Debitorul se poate apăra probând o serie de justificări ale neexecutării. Dintre acestea, doar unele pot constitui o piedică în calea rezoluțiunii. Astfel, de pildă, dacă debitorul probează culpa creditorului (art. 1.517 şi/sau 1.534 C.civ.), creditorul nu este îndreptățit la rezoluțiune pentru că atitudinea debitorului îmbracă, de fapt, forma unei excepții de neexecutare. Dacă însă debitorul probează imposibilitatea fortuită care afectează temporar sau parțial executarea, el nu poate împiedica rezoluțiunea [prin prisma interpretării oferite deja pentru art. 1.557 C.civ. - fiind în această privință nerelevant că regulile rezoluțiunii se aplică „prin analogie” sau în mod direct ${ }^{82}$ ). Un alt exemplu: creditorul

\footnotetext{
${ }^{81}$ Soluție de tradiție în dreptul românesc (v., de pildă, D. Alexandresco, op.cit., T. V, Obligațiile, p. 494 (în special, nota nr. 1).

82 Se subliniază uneori că aplicarea regulilor rezoluțiunii ipotezei de imposibilitate fortuită temporară se face prin analogie, dată fiind formularea art. 1.557 alin. (2) C.civ. Chiar dacă admitem această perspectivă, ea nu schimbă cu nimic regula aplicării rezoluțiunii. In ce
} 
solicită daune-interese pentru neexecutarea prestaţiilor. El va fi ținut să dovedească doar neexecutarea, nu şi condiția vinovăției. Desigur proba va trebui, în opinia noastră să aibă loc diferit după cum avem de a face cu obligații de rezultat (proba neexecutării este proba lipsei rezultatului promis) sau de mijloace (proba neexecutării înseamnă proba nedepunerii diligențelor de către debitor) ${ }^{83}$. Pentru a obține o exonerare de daune-interese, debitorul trebuie să probeze lipsa vinovăției sale, adică ori imposibilitatea fortuită, ori culpa creditorului, ori existența celorlalte cauze care înlătură vinovăția sa în neexecutarea prestațiilor. Are relevanță în această situație, clasificarea tradițională în obligații de mijloace şi obligații de rezultat ?84 Această

priveşte aplicarea celorlalte remedii la imposibilitatea fortuită temporară, aplicarea lor vine în mod natural. De pildă, în ce priveşte excepția de neexecutare, ea este menționată chiar de text care îl autorizează pe creditor să suspende executarea propriilor obligații. In ce priveşte executarea în natură, ea este accesibilă pentru partea din contract neafectată de imposibilitatea fortuită dacă creditorul nu înțelege să opteze pentru rezoluțiune. Dimpotrivă, pentru partea devenită imposibil de executat (în realitate, indiferent dacă ea se datorează culpei debitorului sau unui eveniment fortuit), executarea în natură nu este posibilă [art. 1.527 alin. (1) C.civ.].

83 In această privință s-au emis interpretări diferite ale semnificațiilor art. 1.548 C.civ. Distincția, deja tradițională, făcută între obligațiile de mijloace şi cele de rezultat nu a fost înlăturată de acest text legal deşi el este deopotrivă aplicabil ambelor categorii de obligații (C. Zamşa, în F. A. Baias et alii, op.cit. (2012), pp. 1646 urm.). Suntem de acord că regula prezumării culpei vizează ambele categorii de obligații, dar distincția între ele a fost conservată, deoarece proba neexecutării are loc diferit în funcție de fiecare categorie de obligații: pentru obligațiile de rezultat proba neexecutării o constituie dovedirea neproducerii rezultatului promis, în timp ce, pentru obligațiile de mijloace, proba neexecutării o constituie dovedirea nedepunerii diligențelor de către debitor (L. Pop, în L. Pop, I.F. Popa, S.I. Vidu, Tratat elementar de drept civil. Obligațiile, Universul Juridic, Bucureşţi, 2012, p. 31).

${ }^{84}$ Ptr. autorat, $v$. R. Demogue, Traité des obligations en général. Sources des obligations, t. II, Librairie Arthur Rousseau, Paris, 1925, p. 338 urm.; H. Mazeaud, L'obligation générale de prudence et diligence et les obligations déterminées, în R.T.D. civ., 1936, p. 1 urm.; J. Frossard, De la distinction des obligations de moyens et des obligations de résultat, thèse, Lyon, 1965; B. Starck, H. Roland, L. Boyer, Contrat, Litec, Paris, 1993, pp. 436 urm., nr. 1042 urm.; F. Terré, P. Simler, Y. Lequette, F. Chénedé, op.cit., p. 7 urm., nr. 6; J. Flour, J.-L. Aubert, E. Savaux, Droit civil. Les obligations, V. 1, L'acte juridique, Sirey, Paris, 2012, p. 31 urm., nr. 43 urm.; J. Bellissent, Contribution à l'analyse de la distinction des obligations de moyens et des 
diviziune a fost consacrată expres de art. 1.481 C. civ. Clasificarea respectivă prezintă în continuare relevanță, chiar şi în contextul prezumției generale de vinovăţie instituite de art. 1.548 C.civ. In cazul obligațiilor de rezultat, simpla neprocurare a rezultatului promis generează prezumția de vinovăție în neexecutare. In cazul obligațiilor de mijloace, simpla neatingere a rezultatului promis (folosim terminologia art. 1.481 C.civ.), nu prezumă neexecutarea obligației, fiind necesar să se probeze că acele acte/fapte care constituie diligențele debitorului în atingerea rezultatului nu au fost îndeplinite. Prin urmare, proba neexecutării obligațiilor de mijloace este proba neexecutării diligențelor („toate mijloacele necesare”), în vederea atingerii rezultatului promis. Odată efectuată această probă (proba neexecutării) devine pe deplin funcțională prezumția de vinovăție instituită de art. 1.548 C.civ. In cadrul acestui exemplu, rămâne de lămurit formularea „consecința directă şi necesară a neexecutării fără justificare sau, după caz, culpabile a obligației” prezentă în art. 1.530 C.civ. Sensul acestei formulări se regăseşte într-o subclasificare a obligațiilor de rezultat, în obligații de rezultat relative (care încetează în cazul forței majore) şi obligații de rezultat absolute (care trebuie executate şi în cazul forței majore) ${ }^{85}$. Art. 1.530 C.civ., în formularea sa include toate aceste categorii, oferind posibilitatea acordării daunelor-interese pentru neexecutările culpabile ale obligațiilor de mijloace şi de rezultat relative, ca şi pentru neexecutarea chiar şi neculpabilă a obligațiilor de rezultat absolute (în această categorie de excepție intrând, de fapt, ipotezele tradiționale de

obligations de résultat, L.G.D.J., Paris, 2001, p. 223 urm., nr. 497 urm.; P. Vasilescu, op.cit., p. 12.

${ }^{85}$ Reținută şi în doctrina din țara noastră după modelul său francez - v. L. Pop, Tratat de drept civil. Obligațiile, V. I, Regimul juridic general, C.H. Beck, Bucureşţi, 2006, pp. 63 urm.

892 
răspundere contractuală fără culpă ${ }^{86}$ : obligațiile având ca obiect bunuri de gen şi obligațiile de garanție) $)^{87}$.

c) Soluția potrivit căreia vinovăția nu este o condiție a remediilor se înscrie într-o schemă de interpretare europeană şi internațională în materie de remedii. Această (deja veche) schemă de interpretare se consideră că este datorată cercetării şi concluziilor militante oferite în materia remediilor pentru neexecutarea vânzării de profesorul Ernest Rabel ${ }^{88}$. Sistemul remediilor conceput de Rabel a fost adoptat de Convenția de la Haga privind legea uniformă în materie de vânzare de mărfuri (ULIS/LUVI, 1964) şi şi-a găsit expresia cea mai influentă în Convenția de la Viena privind vânzarea internațională de mărfuri (CISG/CVIM, 1980, art. 45 urm.; art. 61 urm., dar şi art. 25,79 şi 80 CVIM) ${ }^{89}$. De aici, teoria remediilor a făcut carieră europeană şi internațională fiind preluată de art. 7.1.1 urm. P. UNIDROIT9, art. 8:101

\footnotetext{
${ }^{86}$ Bazată, în principiu, pe o prezumție absolută de vinovăție.

${ }^{87}$ Fiind punctul în care, de fapt, se întâlnesc sisteme ale remediilor aparent antagonice $(v$. pentru chiar această observație, dependentă de aceeaşi clasificare/subclasificare a obligațiilor, B. Nichols, art. precit., pp. 340, 355).

${ }^{88}$ Este vorba de E. Rabel, Das Recht des Warenkaufs, V. I (1936) şi V. II (1957), republicate, Walter de Gruyter \& Co, Berlin, 1964 (în special, V. I, pp. 313 urm.; şi întreg conţinutul V. II); $v$. în sensul celor afirmate, J. Kleinschmidt, Non-Performance and Remedies in General, în N. Jansen, R. Zimmermann (ed.), Commentaries on European Contract Laws, Oxford University Press, 2018, p. 1076, nr. 2; H. Kötz, Europäisches Vertragsrecht, Mohr-Siebeck, Tübingen, pp. 300 urm.

${ }^{89}$ Pentru care, $v$., de pildă, M. Torsello, Remedies for Breach of Contract under the 1980 Convention on Contracts for the International Sale of Goods, în F. Ferrari (ed.), Quo Vadis CISG, Bruylant-Sellier, 2005, pp. 43 urm.; P. Huber, CISG - The Structure of Remedies, în Rabels Zeitschrift für ausländisches und internationales Privatrecht, B. 71/2007, pp. 13 urm.; A. Katz, Remedies for Breach of Contract under the CISG, în International Review of Law and Economics nr. 25/2006, pp. 378 urm.

90 Pentru care, $v$. în special, H. Schelhaas, în S. Vogenauer (ed.), Commentary on the UNIDROIT Principles of International Commercial Contracts (PICC), $2^{\text {nd }}$ ed., Oxford, 2014 , pp. 829 urm., respectiv, P. Pichonnaz, în ibidem, pp. 864 urm. (pentru regimul aplicabil imposibilităţii fortuite de executare).
}

\section{3}


urm. PDEC, art. III.-3:101 urm. DCFR ${ }^{91}$, art. 8:101 urm. PCC 92 , art. 131 urm. CESL. In toate aceste exemple, regulile comune sintetizabile sunt aceastea: (i) creditorul are dreptul la remedii pentru orice neexecutare nejustificată; (ii) creditorul are dreptul la remedii şi pentru o neexecutare generată de un eveniment fortuit, cu excepția daunelor-interese şi executării silite în natură; (iii) justificările neexecutării sunt imposibilitatea fortuită şi mora creditoris; (iv) pentru mora creditoris şi în măsura acesteia, debitorul nu poate fi ținut la niciun fel de remedii; (v) daunele-interese pot fi acordate numai dacă neexecutarea nu este justificată 93 . Putem observa că ataşamentul față de condiția vinovăției este aproape inexistent. Inexistența acestui ataşament este legată de cuplul justificare/nejustificare. Dacă nu există justificare, atunci există vinovăție, dacă dimpotrivă există justificare, atunci nu există vinovăție. Credem că această interpretare este în deplin acord cu reglementarea sistemului remediilor din dreptul românesc.

\section{Căutarea răspunsului practic în jurisprudență?}

37. Automatismul vinovăţiei. Dacă analizăm jurisprudența, observăm că, în materiile spinoase, cum ar fi rezoluțiunea sau executarea în natură, condiția vinovăției este una menționată circumstanțial şi că, adesea,

\footnotetext{
${ }^{91}$ Pentru care, $v$. C. von Bar, E. Clive, Principles, Definitions and Model Rules of European Private Law. Draft Common Frame of Reference (DCFR), V. I, Sellier, München, pp. 772 urm. 92 Este vorba de Principes Contractuels Communs elaborate sub egida Association Henri Capitant des Amis de la Culture Juridique Française/ Société de Législation Comparée, Société de Législation Comparée, Paris, 2008, p. 618 urm. (cap. 9 şi 10).

${ }^{93}$ V. J. Kleinschmidt, în N. Jansen, R. Zimmermann (ed.), op.cit., p. 1090 urm., dar mai ales, C. von Bar, E. Clive (Eds.), Draft Common Frame of Reference (DCFR), Full Edition, vol. I, Sellier, München, 2009, p. 772 şi p. 915.
} 
pare un automatism. Aceeaşi jurisprudență relevă un fapt deja cunoscut şi anume acela că nu i se impune cu adevărat creditorului să probeze vinovăția în materie contractuală - observația fiind egal valabilă pentru vechea jurisprudență ca şi pentru cea nouă94. Automatismul menționării vinovăției este însă specific jurisprudenței vechiului Cod civil95.

\section{Cuplul vinovăție/imposibilitate fortuită de executare.}

Observăm, de asemenea, în jurisprudență, cuplul antagonic vinovăție - forță majoră, în numeroase spețe în care este pronunțată rezoluțiunea unui contract şi în care este enumerată şi culpa ca şi condiție a aplicării remediului.

94 Este, de pildă menționată circumstanțial (fiind evident nenecesară) şi acolo unde atât în vechiul cât şi în noul drept civil, se admitea că avem de a face cu o obligație cu privire la care nu operează justificarea neexecutării prin intermediul imposibilității fortuite, cum este obligația de plată a unui preț: „În cazul neexecutării obligației de plată a prețului de către cumpărător, vânzătorul poate alege între mai multe posibilități, respectiv, poate cere obligarea cumpărătorului la executarea în natură a obligației, poate invoca excepția de neexecutare sau poate cere rezoluțiunea contractului, sancțiuni care se aplică contractelor sinalagmatice, la cererea unei părți, ca urmare a neexecutării culpabile a prestației asumate de către cealaltă parte." (ICCJ, dec. nr. 476/07.02.2012, la www.sintact.ro). In acelaşi sens, $v$. ICCJ, dec. nr. 448/02.03.2016, sau s. II. Civ., dec. nr. 58/18.01.2018, ambele la www.sinact.ro). Iată un alt exemplu care porneşte în care motivarea porneşte cu acelaşi automatism al definiției rezoluțiunii şi continuă într-o manieră de neînțeles: „Rezoluțiunea contractului reprezintă o sancțiune care constă în desființarea retroactivă a unui contract sinalagmatic, în cazul neexecutării culpabile a obligațiilor de către una dintre părți, or în situația de față stabilirea culpei presupunea identificarea obligațiilor comerciale nerespectate, iar determinarea acestora nu era posibilă în lipsa contractului încheiat ad probationem.” (aceasta după ce instanța reținuse că s-a încheiat între părți un contract de antrepriză „în formă simplificată” - $v$. ICCJ, dec. nr. 527/10.03.2016, la www.sintact.ro).

${ }^{95}$ De pildă: „Aplicarea mecanismului convențional privind pactul comisoriu de gradul IV a fost determinată de neexecutarea în mod culpabil, de către reclamanta-recurentă a obligațiilor sale (...)” (ICCJ, dec. nr. 3386/01.11.2011, la www.sintact.ro; sau, şi mai evocator: „Rezoluţiunea executarea în natură, excepția de neexecutare sunt sancțiuni care se aplică contractelor sinalagmatice, la cererea uneia dintre părți, ca urmare a neexecutării culpabile a prestației asumate de către cealaltă parte." (ICCJ, dec. nr. 476/07.02.2012, la www.sintact.ro - cu toate acestea, în speță este vorba de neexecutarea obligației de plată a prețului pentru care elementul culpă era şi sub V.C.civ. la fel de nerelevant ca şi sub noul C.civ.).

\section{5}


Intr-o speță, de pildă, s-a reținut că avem de a face cu o neexecutare culpabilă demnă de rezoluțiune a unui antecontract de vânzare-cumpărare atunci când promitentul-vânzător nu a probat existența unei imposibilități fortuite de executare care să îl determine să nu respecte termenele contractuale de predare şi transfer al proprietății considerate esențiale ${ }^{96}$. Speța descrie o situație mai mult decât frecventă în care una din părți invocă rezoluțiunea pentru încălcarea termenelor contractuale. El nu este ținut să probeze vinovăția, iar debitorul nu se poate exonera decât dacă probează imposibilitatea fortuită. Totuşi, este de reținut că în ipoteza imposibilităţii fortuite temporare sunt din nou accesibile remediile curente, cu excepția daunelor-interese.

Cuplul vinovăție/forță majoră este corelat adesea în jurisprudență cu natura obligației. Astfel, într-o decizie ${ }^{97}$, se reține că, în cazul obligației de rezultat (o obligație contractuală de a construi), instanța trebuie să analizeze apărarea debitorului bazată pe forța majoră care l-ar fi împiedicat să construiască, singura împrejurare care i-ar putea oferi o justificare pentru neexecutarea contractuală.

96 ICCJ, dec. nr. 1316/09.03.2012, la www.sintact.ro (o speță cu atât mai relevantă cu cât este întemeiată pe dispozițiile V.C.civ. şî mai ataşat noțiunii de culpă: „Interpretarea coroborată a prevederilor contractuale duce fără echivoc la concluzia la care a ajuns şi instanța de apel potrivit căreia, termenele de predare şi de încheiere a contractului de vânzare-cumpărare în formă autentică erau termene limită cerute şi care nu aveau caracter facultativ. Aceasta rezultă din art. 11 alin. (2) din antecontract, unde sunt limitativ şi expres prevăzute excepțiile care pot determina prelungirea termenului de predare şi care sunt asimilate forței majore. Cum promitentul vânzător nu s-a aflat în niciunul din cazurile asimilate forței majore, prelungirea termenului de predare nu se putea face decât dacă promitenții - cumpărători în calitate de beneficiari ar fi renunțat la beneficiul termenului (...).").

97 ICCJ, dec. nr. 7015/11.10.2011, la www.sintact.ro (în speță, împrejurările relevat sunt prezente obiter în motivație, miza primară fiind revendicarea unui imobil trecut abuziv în proprietatea statului; împrejurările de forță majoră invocate sunt cel de-al doilea război mondial şi apoi regimul totalitar comunist).

\section{6}


Intr-o altă speță, deşi se pomeneşte intens condiția culpei pentru pronunțarea rezoluțiunii, se conchide: „Culpa pârâtei este determinată de sistarea eliberării actelor şi sistarea livrării autovehiculelor solicitate”, adică de chiar neexecutarea obligațiilor contractuale ${ }^{98}$.

39. Alte justificări ale neexecutării. Intr-o altă speță, mai aproape de prezentul sistem al remediilor, se reține că rezoluțiunea a fost corect pronunțată în condițiile în care debitorul (din nou un promitent vânzător care nu şi-a îndeplinit obligațiile la termen) nu a probat că întârzierea în executarea obligațiilor se datorează unui terț sau promitentuluivânzător (în speță, pârâtul invocase culpa antreprenorului său şi fapta promitentului-cumpărător care nu au fost reținute ca şi cauze care să justifice neexecutarea99. Intr-o altă speță, fapta finanțatorului dintr-un contract de leasing de a nu fi predat facturile la timp utilizatorului pentru plată, nu face ca neexecutarea din partea acestuia să fie considerată nejustificată şi nu îl apără de rezilierea leasing-ului câț timp condițiile generale de contractare prevăd expres că neînmnânarea facturilor nu duce la amânarea obligației de

\footnotetext{
98 ICCJ, dec. nr. 2411/21.06.2011, la www.sintact.ro.

${ }^{99}$ ICCJ, dec. nr. 448/02.03.2016, cit. supra, nota 58 (deducem din motivare că fapta terțului subordonat contractual nu poate fi considerată justificare a neexecutării şi nici fapta creditorului dacă ea nu împiedică executarea: „Astfel, deşi recurenta susține că nu a încălcat obligația de predare a imobilului la data convenită aceasta afirmă în acelaşi timp faptul că a depăşit data predării imobilului însă nu din culpa sa ci a antreprenorului general. Şi aceste susțineri sunt nefondate întrucât raportul juridic obligațional dedus judecăţii nu are în vedere exonerarea de răspundere a debitorului obligației de predare a apartamentului pentru fapta unui terț, respectiv antreprenorul general. (...) Potrivit art. 6.1, data predării apartamentului era prelungită în mod corespunzător în cazul în care promitenta-cumpărătoare ar fi solicitat lucrări suplimentare, termenul până la care se făcea prelungirea urmând a fi stabilit în contractul încheiat cu antreprenorul general însă în cauză, reclamanta nu a solicitat efectuarea de lucrări suplimentare în sensul avut în vedere de părți la încheierea antecontractului, prin urmare nu a avut loc o prelungire a datei când urma să fie predat apartamentul. ").
}

\section{7}


platăa10o. Din păcate, toate spețele prezentate, deşi de dată recentă, fac aplicarea V. C.civ.

40. Optica instanțelor în materie de justificări ale neexecutării a devenit ceva mai nuanțată şi conectată la textele legale aplicabile după intrarea în vigoare a noului cod, dar nu sunt de semnalat schimbări majore de optică. Intr-o decizie, se reține, de pildă că creditorul nu se poate prevala de propria omisiune „de a depune diligențele necesare pentru încheierea procesului verbal de recepție parțială, iar lipsa acestuia nu poate să constituie un impediment pentru plata prețului”"101. Intr-o altă hotărâre ${ }^{102}$, se reține că neexecutarea debitorului este justificată de fapta culpabilă a creditorului care a fixat unilateral un termen nerezonabil de scurt de livrare şi execuție pentru ca ulterior să invoce (abuziv) pactul comisoriu din contract. Pe de altă parte, nu constituie o justificare a neexecutării, predarea unor mărfuri defectuoase cauzată de un terț interpus de debitor în executarea contractului, ci o răspundere contractuală pentru fapta altei persoane (art. 1.519 C.civ.) ${ }^{103}$. In

\footnotetext{
100 ICCJ, dec. nr. 827/20.04.2016, la www.sintact.ro. (Cu toate acestea, şî în această speță, instanța nu uită să indice în motivare că rezilierea este o sancțiune ce constă în desființarea cu efecte pentru viitor a contractului cauzată de neexecutarea culpabilă, în pofida faptului că era vorba de o obligație pecuniară pentru care nu poate opera nicio exonerare de răspundere).

101 Trib. Argeş, s. civ., dec. nr. 1625/02.04.2019, la www.sintact.ro (ca urmare a invocării propriei culpe, creditorul nu se poate prevala de clauza penală stabilită în contract în favoarea sa). Intr-o altă speță (Jud. Tulcea, Sent. civ. nr. 841/27.03.2019, www.sintact.ro, instanța reține extrem de ingenios, dar profund discutabil, că reclamanta îşi invocă propria culpă în neexecutarea obligațiilor, culpă care fusese reținută de Curtea de Conturi într-un control anterior prin care se imputase primăriei lipsa de diligență în administrarea propriului patrimoniu.

102 Trib. Bucureşti, sec. VI civ., Sent. nr. 803/27.03.2019, la www.sintact.ro.

103 Trib. Satu Mare, sec. II civ. şi de cont. admin. şi fiscal, dec. nr. 107/16.06.2017, la www.sintact.ro (în hotărâre se vorbeşte şi de anumite omisiuni ale creditorului care au fost invocate ca scuză a executării defectuoase de către debitor, dar se reține că acestea nu au fost suficient de serioase pentru a împiedica executarea).
}

\section{8}


fine, printr-o altă decizie, se reține că reprezintă o justificare a neexecutării fapta uneia din părți de a nu oferi celeilalte posibilitatea de a-şi executa obligațiile contractuale ${ }^{104}$.

\section{Remediile după intrarea în vigoare a Codului civil. Există}

însă şi hotărâri în care chestiunea vinovăției este tratată corect - de pildă, într-o hotărâre se reține că simpla neexecutare este suficientă pentru invocarea unui pact comisoriu (era vorba de acumularea unor restanțe în plata chiriei ajungând la un anumit prag valoric) şi obiter şi că excepția de neexecutare poate fi invocată în fața unei neexecutări, fără ca aceasta să fie culpabilă $^{105}$. Intr-o altă speță, se reține că simpla neexecutare necorespunzătoare a obligațiilor contractuale este un motiv suficient pentru o rezoluțiune parțială a contractuluii ${ }^{106}$.

\section{Remarcă pe marginea jurisprudenței remediilor.}

Impresia pe care ne-o creează investigarea jurisprudenței în materie de remedii este aceea că, atunci când judecățorul este pus în fața neexecutării, el presupune constructiv existența unei culpe. Probabil că această presupunere este specifică şi dreptului de după 2011, câț şi dreptului anterior. Astăzi, lipsa relevanței vinovăţiei este legată de prezumția de vinovăție instituită de textele

\footnotetext{
${ }^{104}$ In speță este vorba de aducerea clădirii unde trebuiau montate instalațiile de aer condiționat la un nivel de finisare suficient pentru montarea acestor instalații (clădirea fiind ridicată doar în faza structurii de rezistență) - C. Ap. Timişoara, sec. II civ., dec. nr. 228/A/31.03.2014, la www.sintact.ro.

105 ICCJ, dec. nr. 489/08.03.2016, la www.sintact.ro.; în acelaşi sens, cu menționarea condițiilor formale şi substanțiale ale rezoluțiunii şi cu omiterea deliberată a vinovăției dintre acestea, $v$. C. Ap. Cluj, s. II civ., dec. 209/06.04.2017, la www.sintact.ro.

106 Tribunalul Satu Mare, s. II civ., dec. nr. 107/16.06.2017, la www.sintact.ro („În prezența existenței unei împrejurări de fapt dovedite de neexecutare corespunzătoare a obligațiilor contractuale asumate, instanța de apel constată îndeplinite în cauză condițiile rezoluțiunii parţiale a contractului prevăzute de art. 1549 C .civ. şi cele ale răspunderii civile contractuale prevăzute de art. 1530 C .civ.”).
}

\section{9}


din materia daunelor-interese. Dacă debitorul nu a executat, el este prezumat vinovat. Aşadar, când creditorul invocă un remediu, nu trebuie să insiste în vreo probare a vinovăției. In majoritatea spețelor indexate mai sus vinovăția este indicată formal ca şi condiție a remediilor şi nu se pune proba ei. Poate că ar prezenta interes dezbaterea în cazul unei obligații de mijloace, dar nu am identificat o hotărâre relevantă în această privință. Cu toate acestea, un alt aspect pare să nu fie încă absorbit de jurisprudență şi anume acela că marea parte a remediilor sunt disponibile şî pentru imposibilitățile fortuite de executare.

\section{Concluziile}

43. Din prezentarea de mai sus am putea extrage mai multe concluzii. Chiar dacă se poate admite că unele dintre acestea sunt o interpretare voită a textelor legale, cred că niciuna din ele nu "forțează" textele legale. Concluziile ar fi:

44. Culpa este înrudită istoric cu buna-credință, în sensul că prima îşi are originea în dezvoltarea doctrinei cu privire la a doua, adică în procedurile formulare romane care au dat naştere acțiunilor contractuale întemeiate pe buna-credință. Definiția vinovăției oferită de jurisconsulții romani îşi păstrează şi astăzi actualitatea şi are o aplicabilitate universală, atât pentru răspunderea contractuală, cât şi pentru cea extracontractuală. Inrudirea culpei cu buna-credință este bazată pe o relație complexă care presupune identificarea lipsei vinovăției cu buna-credință, dar nu şi a opusurilor acestora, în sensul că vinovăția nu este egalul relei-credințe. In această privință, trebuie să reținem că reaua-credință este egalul vinovăției calificate (care include tradițional intenția şi neglijența gravă). 
45. In mod tradițional, vinovăţia a fost văzută în sistemele de drept continental ca o condiție a activării mijloacelor pe care creditorul le are la îndemână în caz de neexecutare din partea debitorului. Această tendință, manifestă în reglementările marilor codificări europene este în evident declin tehnic. Tendința modernă este aceea de a elimina vinovăția din rândul condițiilor de activare a remediilor.

46. $\mathrm{Cu}$ toate acestea, între vechea şi noua optică nu există un clivaj. Este vorba de o evoluție a tehnicii juridice care simplifică şi ajută la sistematizarea remediilor preluând concluziile vechii tendințe: a) remediile sunt accesibile pentru orice neexecutare nejustificată; b) remediile sunt accesibile şi pentru neexecutarea cauzată de imposibilitatea fortuită, cu excepția executării în natură şi daunelor-interese; c) dacă debitorul nu probează o cauză justificată de neexecutare a obligațiilor, atunci neexecutarea îi este imputabilă (i.e. este vinovat de ea); d) există câteva cazuri în care neexecutarea chiar dacă nu este imputabilă, este prezumată de legiuitor imputabilă, deci vinovată (e.g. cazul obligațiilor de garanție şi cel al obligațiilor având ca obiect bunuri de gen).

47. Răspunsul la întrebarea secundară legată de daunele-interese şi înțelesul art. 1.530 C.civ. este legat de clasificarea oferită obligațiilor de rezultat în obligații de rezultat relative şi absolute. In esență, vinovăția este o condiție pentru acordarea daunelor-interese în cazul tuturor obligațiilor de mijloace şi a obligațiilor de rezultat relative (adică a acelor obligații cu privire la care exonerarea de răspundere poate avea loc în ipoteza forței majore). Vinovăția nu este însă o condiție pentru acordarea daunelor-interese în cazul neexecutării obligațiilor de rezultat absolute (pentru care nu operează exonerarea de răspundere contractuală nici măcar în cazul forței majore - e.g. obligațiile care au ca obiect plata unei sume de bani sau predarea unor alte 
bunuri de gen). In această ultimă situație se poate vorbi de o răspundere contractuală obiectivă. 